\title{
Nieznane losy pierwszego ihumena supraskiego
}

Monaster supraski był w XVI wieku jednym z największych prawosławnych ośrodków zakonnych na ziemiach Wielkiego Księstwa Litewskiego ${ }^{1}$. Na temat jego powstania i dziejów ukazały się liczne opracowania w historiografii polskiej i obcej². Nadal niewiele wiemy o jego założycielach i pierwszym

1 O roli monasteru supraskiego w dziejach Kościoła prawosławnego por. Николай (Далматов), Супрасльский Благовещенский монастьрь, Санкт-Петербург 1892; Модест (Стрельбицкий), Супрасльский Благовещенский монастьрь, „Вестник Западной России”, Вильна 1867, г. V, кн. 7, s. 70-81; А. И. Рогов, Супрасль как один из иентров культурных связей Белоруссии с другими славянскими странами, [w:] Славяне в эпоху фееодализма, Москва 1978, s. 321-334; A. Mironowicz, Supraśl jako ośrodek kulturalno-religijny w XVI wieku, Leiman 1984.

2 Za podstawowe należy uznać prace: S. Alexandrowicz, Nowe źródto ikonograficzne do oblężenia Połocka w 1579 r., „Kwartalnik Historii Kultury Materialnej” 1971, R. XIX, z. 1; А. Белецкий, Митрополитъ Іосифъ II Солтанъ и отношение его къ Супрасльскому монастырю, Вильна 1899; В. А. Чантурия, История архитектуры Белоруссии, Минск 1969; M. Cubrzyńska-Leonarczyk, Oficyna supraska 1695-1803, Warszawa 1993; Николай (Далматов), Супрасльский Благовещенский монастьрь, Санкт-Петербург 1892; Модест (Стрельбицкий), Супрасльский Благовещенский монастырь, „Вестник Западной России. Историко-литературный журнал", г. V, кн. 2, т. I, отд. 2, Вильно 1867; Ф. Н. Добрянский, Описание рукописей Виленской публичной библиотеки, иерковнославянских и русских, Вильна 1882, s. XXVII-XXXIII; M. Hajduk, Sanktuarium nad Supraśla, „Slavia Orientalis”, t. XXXVIII, nr 3-4, 1989; И. И. Иодковский, Церкви, приспособленные к обороне в Литве и Литовской Руси, „Древности”, t. VI, Москва 1915; М. С. Кацэр, Белорусская архитектура, Минск 1969; W. Kochanowski, Pobazyliański zespót architektoniczny w Supraślu, „Rocznik Białostocki” 1963, nr 4; Z. Lebiedzińska, Freski z Supraśla. Katalog wystawowy, Kraków 1968; J. Maroszek, Kalendarium klasztoru Ojców Bazylianów w Supraślu - czasy Aleksandra Chodkiewicza, „Białostocczyzna” 1994, nr 2(34); A. Mironowicz, Kodeks supraski, „Białostocczyzna” 1988, nr 1(9); idem, Zwiazki literackie Kijowa z monasterem supraskim w XVI wieku, „Slavia Orientalis” 1989, t. XXXVIII, nr 3-4; idem, Podlaskie ośrodki i organizacje prawosławne w XVI i XVII wieku, Białystok 1991; idem, Tożsamość $i$ tolerancja $w$ rozumieniu prawosławnych zakonników supraskich w XVI wieku, „Rocznik Teologiczny” 1998, R. XL, z. 1-2; idem, Życie monastyczne na Podlasiu, Białystok 1998; idem, Największa fundacja Aleksandra Chodkiewicza. Spór o charakter fundacji, [w:] Władza i prestiz. Magnateria Rzeczypospolitej w XVI-XVIII wieku, (red.) 
przełożonym ośrodka zakonnego. Według najnowszych ustaleń początki klasztoru sięgają roku 1495, kiedy wojewoda nowogródzki i marszałek hospodarski Aleksander Chodkiewicz (ok. 1457-1549) ufundował zgromadzenie zakonne w pobliżu Gródka. Data ta jest wielce prawdopodobna, zważywszy, że wcześniej została uwolniona z jasyru tatarskiego żona Iwana Chodkiewicza - Agnieszka z synem Aleksandrem i córką Agrafeną. Wracając ze Złotej Ordy Chodkiewiczowie zaprosili uciekających przed Turkami mnichów. Według tradycji ustnej owi mnisi mieli pochodzić ze św. Góry Athos i z Kijowa³. Pogląd ten uwiarygodnia ogromne doświadczenie duchowe mnichów już na początku XVI wieku, posiadanie przez nich licznej literatury religijnej i ksiąg liturgicznych z Bałkanów oraz późniejsze ścisłe kontakty monasteru supraskiego ze św. Górą Athos 4 . Szczególną rolę przy powstaniu wspólnoty monastycznej w Gródku nad rzeką Supraśl odegrał Pafnucy Sieheń i Aleksander Chodkiewicz 5 . Na prośbę ihumena

J. Urwanowicz, Białystok 2003; A. Mironowicz, Summariusz dokumentów do dóbr supraskich, Białystok 2009; idem, Sumariusz dokumentów dóbr supraskich, t. II, Białystok 2011; idem, Powstanie monasteru supraskiego, „Białostockie Teki Historyczne” 2012, $\mathrm{nr}$ 10; idem, O początkach monasteru supraskiego i jego fundatorach, Supraśl 2013; M. Morelowski, Zarys syntetyczny sztuki wileńskiej od gotyku do neoklasycyzmu z przewodnikiem po zabytkach między Niemnem a Dźwina, Wilno 1939; М. А. Оболенский, Супрасльская рукопись, содержащая Новгородскую и Киевскую сокращенные летописи, Москва 1836; С. Петковић, Нектарие Србин, сликар XV v., „Зборник за ликовне уметности”, нр. VIII, Нови Сад 1972; Н. И. Петров, Супрасльский монастырь как защитник православия в XVI и в начале XVII века, „Виленский календарь на 1896 год”, Вильно 1895; П. П. Покрышкин, Благовещенская иерковь в Супрасльском монастыре, [в:] Сборник археографических статей поднесеный графу А. А. Бобринскому, Санкт-Петербург 1911; А. И. Рогов, Литературные связи Белоруссии с балканскими странами в XV-XVI вв., [в:] Славянские литературы. VIII Международный съезд славистов, Загреб-Любляна, сентябрь 1978 г. Доклады советской делегации, Москва 1978; idem, Фрески Супрасля, [в:] Древнерусское искусство. Монументальная живопись XI-XVII вв., Москва 1980; A. Siemaszko, Malowidła ścienne cerkwi Zwiastowania w Supraślu. Rekonstrukcja programu ikonograficznego, „Zeszyty Naukowe Uniwersytetu Jagiellońskiego. Prace z Historii Sztuki” 1996, z. 21; St. Stawicki, Czy Nektarij autor „Typika” byt autorem malowidet supraskich?, „Biuletyn Historii Sztuki” 1972, R. XXXIV, nr 1; Супрасълски или Ретков сборник, Й. Заимов, увод и коментар на старобългарски текст, М. Капалдо, подбор и коментар на гръцкия текст, t. I, София 1982, t. II, София 1983; Супрасльская летопись, [в:] Полное собрание русских летописей (dalej: ПСРЛ), t. XXXV, Москва 1980; S. Szymański, Freski z Supraśla. Próba rekonstruowania genealogii, „Rocznik Białostocki” 1972, t. XI; A. Szyszko-Bogusz, Warowne zabytki architektury kościelnej w Polsce i na Litwie, [w:] Sprawozdanie Komisji do badań nad historia sztuki w Polsce, t. IX, z. 3-4, Kraków 1914; 500 lat monasteru w Supraślu, Supraśl 1998.

3 Модест (Стрельбицкий), Супрасльский Благовещенский монастырь, „Вестник Западной России" 1867, г. V, кн. 7, т. 2, отд. 2, s. 71-72.

4 A. Mironowicz, Związki monasteru supraskiego ze Święta Góra Athos w XVI wieku, [w:] Święta Góra Athos w kulturze Europy. Europa w kulturze Athos, (red.) M. Kuczyńska, Gniezno 2009, s. $122-134$.

5 J. Jasnowski, Chodkiewicz Aleksander, Polski Stownik Biograficzny (dalej PSB), t. III, Kraków 1937, s. 354; Por. wypisy Józefa Wolffa dotyczące Chodkiewiczów zamieszczone w artykule Zyg- 
Pafnucego Siehenia Aleksander Chodkiewicz ok. 1497 roku wybudował bądź wyremontował zamek obronny, który miał bronić monasteru.

\section{Pafnucy - ihumen supraski}

Powstanie monasteru wiąże się z osobą Pafnucego Siehenia, pierwszego ihumena i autora Субботника или Помянника ${ }^{6}$ Субботник или Поминник monasteru supraskiego, w którym pierwszy ihumen supraski Pafnucy zaczął wpisywać imiona zmarłych braci, powstał w roku założenia monasteru. Do poznania okoliczności powstania monasteru i roli w tym procesie ihumena Pafnucego Siehenia mamy dwa źródła: Kronikę Ławry Supraskiej, która została napisana przed 1748 rokiem, czyli dwa i pół stulecia po powstaniu monasteru ${ }^{7}$ i wspomniany wyżej Субботник или Поминник. O ihumenie Pafnucym, jako założycielu monasteru supraskiego i pierwszym jego przełożonym, informuje cytowany wyżej wpis do oryginalnego Субботника или Помянника ${ }^{8}$. Informacje о ihumenie

munta Luby-Radzimińskiego, gdzie stwierdzono: „Około tego czasu (1495) pan Aleksander (...) zapisuje fundusz na monaster supraślski”. Z. Luba-Radzimiński, Sprawa odrębnego pochodzenia Chodkiewiczów litewskich i białoruskich, „Rocznik Polskiego Towarzystwa Heraldycznego”, t. VIII, R. 1926-1927, Kraków 1928, s. 109-132. O rodzie Chodkiewiczów i jego przedstawicielach K. Niesiecki, Herbarz polski, t. III, Lipsk 1839, s. 48-63; J. Kamiński, Rodzina Chodkiewiczów herbu Gryf, „Skarbiec Polski” 1859; S. K. Kossakowski, Monografie historyczno-genealogiczne niektórych rodzin polskich, t. I, Warszawa 1876, s. 40-64; T. Żychliński, Złota księga szlachty polskiej, R. XI, Poznań 1889, s. 1-34; A. Boniecki, Herbarz polski, t. III, Warszawa 1900, s. 21-29; S. Uruski, Rodzina, t. II, Warszawa 1905, s. 207-215.

6 A. Mironowicz, Najstarszy Субботник или Поминник monasteru supraskiego, „Białoruskie Zeszyty Historyczne" 2013, nr 40, s. 233-243.

7 АСД, t. IX, s. IV. Jego autorem był unicki hieromnich Mikołaj Radkiewicz, który znał wydarzenia sprzed 250 laty jedynie z innych dostępnych mu przekazów pisemnych. Mnich ten nie dbał o ustalenie prawdziwych faktów historycznych, a jedynie starał się udowodnić unickie początki monasteru. Wersja rękopiśmienna Kroniki Ławry Supraskiej znajduje się w zbiorach Biblioteki Litewskiej Akademii Nauk w Wilnie, B 2, nr 134. Źródło we fragmentach zostało opublikowane w АСД, t. IX, Вильно 1870. Por.: J. Maroszek, Rewelacyjne odkrycie nieznanych najstarszych dokumentów dla Białegostoku, „Białostocczyzna” 1999, nr 1 (53), s. 5-30. Istniała jeszcze inna, zaginiona, kronika supraska pod łacińskim tytułem Traditio de translatione fratrum religiosum Grodeco-Supraslum, nie wiadomo kiedy i przez kogo napisana w XVIII wieku. Na ową kronikę powoływał się archimandryta wileński Modest (Strelbickij) w swej monografii o monasterze supraskim z 1867 roku. Модест (Стрельбицкий), Супрасльский Благовещенский монастырь, „Вестник Западной России”, г. IV, кн. 7, t. III, отд. 2, Вильно 1865/1866, Приложения, nr 1, s. 72. Por.: „Вестник Западной России”, г. V, кн. 7, t. II, отд. 2, 1867, s. 71.

8 Модест (Стрельбицкий), Супрасльский Благовещенский монастырь, „Литовские Епархиальные Ведомости" 1865, nr 3, s. 75-76; Модест (Стрельбицкий), Супрасльский Благовещенский монастырь, „Вестник Западной России. Историко-литературный журнал”, г. V, кн. 6, t. II, отд. 2, Вильно 1867, s. 128-131; А. Белецкий, Митроплитъ Іосифъ II Солтанъ и отношение его къ Супрасльскому монастьрю, s. 5-6. 
Pafnucym jako założycielu klasztoru z Субботника или Поминника mógł zawierać odnotowany w „Описи” „летописецъ церковный, што на тябле”, czyli tablica umieszczona na ikonostasie. Niestety, są to jedynie domysły niepotwierdzone w innych źródłach.

O ihumenie Pafnucym, jako założycielu klasztoru, znajdujemy informację w narracji o powstaniu monasteru w Kronice Ławry Supraskiej:

Najprzód roku 1498 w Gródku tę ławrę albo monaster fundować zaczął Pan Miłościwy Aleksander Chodkiewicz, wojewoda nowogródzki i marszałek wielki W. X. Lit. w dobrach swoich dziedzicznych, stąd o mil cztery, y tam na pierwszym tym funduszu osadził był zakonników św. Bazylego Wielkiego, żadnych jeszcze nie czyniąc im zapisów, i pierwszy był superior albo hegumen Paphnutiusz Sieheń. A gdy się te miejsce w lat dwie nie podobało zakonnikom (...) prosili fundatora [Aleksandra Chodkiewicza - A. M.], aby na innym spokojniejszym miejscu ich ufundował. Ten Pan świątobliwy, pozwolił im onego samym upatrywać, i obrać. A tak już mając fundatora konsens, zrobili krzyż drewniany, i puścili z Gródka rzeką Supraślem, tą intencją, gdzie na którym miejscu stanie, tym się mieli kontentować (...).

Tradycja głosi, że mnisi, pomodliwszy się, puścili na wodę krzyż z cząstką „świętego drzewa" ${ }^{10}$. Według tego źródła, na początku wybudowano niewielką drewnianą cerkiew św. Jana Teologa i cele dla braci. W kronice znajduje się informacja, że za ihumena Pafnucego w 1503 roku rozpoczęto budowę wielkiej cerkwi. Wspomniane zapisy o budowie cerkwi wskazują, że dotyczyły one świątyń w Gródku. „У пана Александра Ивановича Ходкевича у отчизной пущи Блудовской, на край рекы Супрасли" ${ }^{11}$. Z okazji wyświęcenia nowej cerkwi biskup smoleński Józef ofiarował monasterowi bogato ozdobioną Ewangelię, a metropolita Iona III (1502-1507) krzyż z cząstką Krzyża Świętego ${ }^{12}$. $\mathrm{Z}$ napisu na bocznych ściankach krzyża wynika, że dar metropolity Iony nastąpił w obecności biskupa smoleńskiego Józefa, władyki turowsko-pińskiego Was-

9 „Опись вещам Супрасльскаго монастыря”, АСД, t. IX, s. 52. Por.: Н. Н. Улащик, Введение в изуиение белорусско-литовского летописания, Москва 1985, s. 35.

10 АСД, t. IX, s. 1-2.

11 Ibidem, s. 17. Pośrednio taki przebieg wydarzeń potwierdza list Zygmunta I z 12 listopada 1508 roku do wojewody trockiego Mikołaja Mikołajewicza Radziwiłła (1505-1510) nakazujący wziąć pod opiekę dobra i poddanych monasteru nad rzeką Supraśl. AP w Krakowie, AMCh, sygn. 36, nr 29. Strony dodatkowe $\mathrm{nr} 1$.

12 Metropolita Iona otrzymał zdobiony krzyż z cząstką Krzyża Świętego od królowej Heleny, która z kolei dostała go w 1503 roku od swej matki Zofii Paleolog. Żona cara Iwana III przekazała tę bezcenną relikwię córce będąc na łożu śmierci. Е. Церетели, Елена Иоанновна, великая княгиня литовская, русская, королева польская, Санкт-Петербург 1899, s. 242; Е. Раре́е, Aleksander Jagiellończyk, Kraków 1949, s. 71-72. 
siana II (1500-1512), ordynariusza diecezji chełmskiej Aleksandra (1503-1504) ${ }^{13}$ oraz wielu innych osób duchownych i świeckich ${ }^{14}$.

Obecność na uroczystości tylu dygnitarzy duchownych i świeckich wskazuje na rangę tego ośrodka. Czy takie spotkanie byłoby możliwe na terenie do tego nieprzygotowanym, w samej puszczy? Przyjazd metropolity Iony z trzema biskupami (Józefem, Wassianem, Aleksandrem) był wielkim wydarzeniem, które miało miejsce w zamku Aleksandra Chodkiewicza. Nie mniej kosztowny był inny podarunek władyki smoleńskiego. Biskup przekazał monasterowi kopię ikony Matki Bożej Smoleńskiej, która wkrótce stała się obiektem wielkiego kultu' ${ }^{15}$. Ofiarowanie przez metropolitę kijowskiego Ionę monasterowi krzyża z cząstką Krzyża Świętego mogło nastąpić w dniu poświęcenia wielkiej cerkwi w 1503 roku, o czym wspomina się w Субботникы или Поминникы ${ }^{16}$. Fakt ten podważa

13 Chodzi tu o biskupa chełmskiego Aleksandra - Aleksego Zbaraskiego. Kniaź Aleksander Zbaraski zmarł w 1504 roku. А. Петрушевич, Холмская епархия и святители ее, Львов 1867, s. 32. Б. И. Ульяновський, Історія иеркви та релігійної думки в Україні у трьох книгах. Кн. 1: Середина XV - кінец XVI столітmя, Київ 1994, s. 103; J. Wolff, Kniaziowie litewsko-ruscy od końca czternastego wieku, Warszawa 1895, s. 618.

14 Wśród nich wymienia się, tylko z imienia, księcia Wasyla, „rabowie Boży”: Stefana, Sidora, Semeona, Grzegorza, Michała, Iwana, Ionę, Iwana, Tymoteusza, Filimona, Andrzeja, Akinta, Sisosa - ikonografa, Własa i ihumena Pafnucja. Николай (Далматов), Супрасльский Благовещенский монастырь, s. 456. Imiona osób świeckich i duchownych wskazują, że były to następujące osoby: ihumen supraski - Pafnucy, protopop wileński - Tymoteusz, archimandryta ławryszewski - Iona. Imiona nie pozwalają dokładnie ustalić kim były wszystkie osoby biorące udział w akcie obdarowywania. Prawdopodobnie książę Wasyl to książę Wasyl Lwowicz Gliński, podstoli litewski (1501-1507); Stefan - to Stefan Czapla, bojarzyn Aleksandra Chodkiewicza; Grzegorz - to Hrehory Isajewicz Hromyka, diak, pisarz wielki litewski (1499-1533); Michał - to Michał Lwowicz Gliński, marszałek nadworny (1500-1506), Semen Jurjewicz Holszański marszałek ziemi wołyńskiej (1501-1505); pierwszy z Iwanów to Iwan Iwanowicz Zabrzeziński - marszałek hospodarski (1503-1516), a drugi - Iwan Semenowicz Sapieha, kanclerz królowej Heleny (1501-1506); Sisosa - ikonograf, to Sisoj (Sysoja) diak, pisarz wielki litewski (1495-1503).

15 А. Белецкий, Митрополитъ Іосифъ ІІ Солтанъ и отношение его къ Супрасльскому монастырю, s. 19; Николай (Далматов), Супрасльский Благовещенский монастырь, s. 455$-456,464$.

$16 \mathrm{Na}$ pierwszych kartach oryginalnego tekstu znajdowały się zapisy o charakterze kronikarskim, które informowały o powstaniu klasztoru. „В лето от начала мира 7008, индикта 3, от Рождества Христова 1500, дозволеніем вельможнаго пана Александра Ивановича Ходкевича начат съзидатися сей монастырь у его отчиной пущи Блудовской на край реки Супраслы. Верую и любовію желаніем и трудом многогрешнаго священно-инока Пафнотія, родом из Бельска. И перве съоружися церков невелика во имя святаго Іоанна Богослова и святися нареченным митрополитом Іосифом и трапеза на прихожденіе братіи. Потом в лето 7011, индикта 7, от Рождества Христова 1503, съоружена бысть великая церква Пречистыя Богоматери, Честнаго Ея Благовещенія, со приделы святых великомучеников Бориса и Глеба, нареченных во св. крещеніи Романа и Давида и преподобных св. Отец строителей Печерских и начальник общему житію, Антонія и Феодосія, Богоспасаемаго града Кіева в Рускей земле. Сія же Божія церкви освящены были освященным епископом, нареченным митрополитом Кіевским и всея Руси кнр Іоною, месяца октябра в 15 день, на память преподобнаго отца 
wiarygodność legendy o spuszczeniu krzyża rzeką Supraśl w 1500 roku. W tym bowiem roku mnisi koło Gródka nie posiadali takowej relikwii.

$\mathrm{Z}$ zapisu Субботника или Поминника wynika, że założycielem monasteru był Pafnucy Sieheń pochodzący z Bielska. Ihumen Pafnucy świadomie dokonał zapisu w Субботнику или Помяннику swego mieszczańskiego rodu wśród metropolitów, biskupów, panujących, kniaziów prawosławnych i innych dygnitarzy z Wielkiego Księstwa Litewskiego. „Здł родъ Пахнотіевъ и пана Ивана Сегеневичъ изъ братіею его" ${ }^{17}$. Sieheniewicze zostali potraktowani na równi z dostojnikami duchownymi i świeckimi. Powstaje pytanie, czy takie wyeksponowanie rodziny wynikało li tylko z tego, że pierwszym ihumenem supraskim był pochodzący $\mathrm{z}$ tego rodu Pafnucy, czy też wynikało z faktu, że został on w latach następnych ordynariuszem dwóch najbogatszych diecezji prawosławnych: włodzimiersko-brzeskiej (1512-1522) i łucko-ostrogskiej (1523-1528). Szczególny szacunek i uznanie rodzina Sieheniów miała też z innych powodów.

Pafnucy Sieheń został nie tylko założycielem monasteru, ale jego pierwszym przełożonym. On to przyczynił się głównie do powstania pierwszych świątyń, zabezpieczenia materialnego klasztoru i określenia jego statusu w Cerkwi. Nie ulega wątpliwości, że to rodzina Sieheniów poniosła koszty założenia wspólnoty monastycznej w Gródku. Trudno uwierzyć, że takimi środkami dysponowali niedawno uwolnieni z niewoli tureckiej Chodkiewiczowie. Nie znamy też innych współfundatorów owego przedsięwzięcia. Wybranie na przełożonego monasteru Pafnucego Siehenia, rodem z okolicznego Bielska, a nie doświadczonego mnicha ze św. Góry Athos czy Kijowa nasuwa przypuszczenie, że we współfinansowaniu pierwszych budynków klasztornych uczestniczyli przedstawiciele rodu Sieheniewiczów. Субботник или Поминник podaje jednoznacznie, że monaster powstał „верую и любовію желаніем и трудом многогрешнаго священно-инока Пафнотія, родом из Бельска". А więc nieprzypadkowo w tym źródle przedstawiciele tego rodu zostali wpisani po prawosławnych metropolitach, biskupach i najwybitniejszych dygnitarzach świeckich, zaraz po królowej Helenie. Prawdopodobnie w fundacji monasteru uczestniczył burmistrz Bielska Iwan Siehenie-

нашего Евфимія новаго и св. Мученика Лукіана, пресвитера великія Антіохіи, индикта 7". Biblioteka Litewskiej Akademii Nauk w Wilnie, f. 19, nr 89, k. 8; АСД, t. IX, s. 454-459; Е. Н., Старый Синодик Супрасльского монастьия; „Гродненские Епархиальные Ведомости”, Годъ IV, 1904, nr 27, s. 789; Ф. Н. Добрянский, Описание рукописей Виленской публичной библиотеки, церковнославянских и русских, nr 89, s. 180; Николай (Далматов), Супрасльский Благовещенский монастырь, s. 7; А. Белецкий, Митрополитъ Іосифъ II Солтанъ и отношение его къ Супрасльскому монастырю, s. 5-6.

17 Biblioteka Litewskiej Akademii Nauk, f. 19, nr 89, s. 180; Николай (Далматов), Супрасльский Благовещенский монастырь, s. 7. 
wicz, prowadzący rozległe interesy z Chodkiewiczami, Radziwiłłami, Sapiehami i innymi urzędnikami hospodarskimi ${ }^{18}$.

Sieheniewiczowie, którzy współfinansowali budowę monasteru, uzyskali tereny do wyrębu i prawo handlowania drzewem w Puszczy Błudowskiej ${ }^{19}$. Iwan Sieheniewicz i jego brat Wasyl otrzymali 10 lutego 1514 roku od króla Zygmunta Starego potwierdzenie na ziemię w Studziwodach (Iwan) oraz Puchałowszczyznę i Hryniewicze (Wasyl). Z dokumentu tego możemy wywnioskować, że król Aleksander nadał Studziwody przodkowi Iwana Siehenia - Protasowi Tyszkiewiczowi, które następnie przeszły na rzecz jego i jego żony. Z kolei brat Iwana Siehenia - Wasyl - nabył od ziemianina bielskiego Mikołaja Petrykowskiego dwie wsie Puchałowszczyznę i Hryniewicze (Hryniewszczyzna). Ponadto, Iwan Sieheń otrzymał zgodę na założenie w dobrach Studziwodskich młyna na rzece Białej, który został nazwany „Rimarewski”. Do tego młyna Zygmunt Stary dodał Iwanowi Sieheniowi kawałek pola po rzekę w kierunku Szydłowa i drogę brzeską ${ }^{20}$.

Funkcjonowanie monasteru w pobliżu dworu w Gródku nad rzeką Supraśl okazało się niewygodne. Życie dworskie utrudniało praktyki religijne, a zwłaszcza prowadzenie życia pustelniczego przez mnichów. $\mathrm{Z}$ tego powodu ihumen z mnichami poprosili Aleksandra Chodkiewicza o pozwolenie na przeniesienie klasztoru na inne miejsce ${ }^{21}$. Mnisi poprosili o przeniesienie klasztoru w dół rzeki Supraśl. Na prośbę ihumena Pafnucego Siehenia Aleksander Chodkiewicz, „намовившися" z osobami duchownymi, wyraził zgodę na nową lokalizację. Owe zdarzenie miało miejsce nie wcześniej aniżeli w 1507 roku, poniważ drugi fundator monasteru biskup smoleński Józef Sołtan (1504-1507) został metropolitą kijowskim dopiero w maju 1507 roku. Część mnichów powróciła do Kijowa, a pozostali przenieśli się na uroczysko Suchy Hrud, dając początek Ławrze Supra-

18 J. Maroszek, Pogranicze Litwy i Korony w planach króla Zygmunta Augusta: z historii dziejów realizacji myśli monarszej między Niemnem a Narwia, Białystok 2000, s. 144; A. Boniecki, Poczet rodów w Wielkim Księstwie Litewskim w XV i XVI wieku, s. 309.

19 J. Maroszek, Monografia miasta i gminy Supraśl, Supraśl 2013, s. 55.

20 „Lietuvos Metrika” (1511-1518), Knyga nr 9, Vilnius 2002, nr 280, s. 202-203.

21 Archimandryta Modest przyjmuje rok przeprowadzki po 1500, ale wówczas Józef Sołtan nie był nawet biskupem. Również podana przez niego informacja o wyświęceniu nowej cerkwi na Suchym Hrudzie św. Jana Teologa 25 maja 1505 roku nie znajduje żadnego logicznego wytłumaczenia. Biorąc pod uwagę okres, kiedy biskup Józef został „nareczenyj” na metropolitę pośrednio datę roczną decyzji o przeniesieniu na nowe miejsce można wyznaczyć na drugą połowę 1507 roku. Модест (Стрельбицкий), Супрасльский Благовещенский монастьрь, „Вестник Западной России", г. V, кн. 7, т. 2, отд. 2, 1867, s. 71-73. Warto przypomnieć, że chirotonia biskupa Józefa Sołtana na metropolitę odbyła się 10 maja 1507 roku „Вестник Западной России”, г. IV, кн. 7, т. III, отд. 2, Вильно 1865/1866, s. 2. Władyka Józef był „nareczennyj” jeszcze 26 lutego 1508 roku, Lietuvos Metrika (1499-1514), Knyga nr 8, Vilnius 1995, nr 110, s. 143. 
skiej ${ }^{22}$. Jeżeli pomysł przeniesienia monasteru pojawił się w 1507 roku, to klasztor nie mógł od razu rozpocząć swojego funkcjonowania na nowym miejscu. Potrzebna była budowa nowych świątyń na uroczysku Suchy Hrud. Prawdopodobnie mnisi pozostawali w Gródku w pobliżu zamku Chodkiewiczów do końca 1507 roku. W źródłach informujących o monasterze do jego przeniesienia nie ma danych odnośnie do jego lokalizacji, ponieważ wyznacznikiem był zamek Chodkiewiczów. Dopiero późniejsze akta precyzyjnie lokują nową siedzibę klasztoru na brzegu rzeki Supraśl, na uroczysku Suchy Hrud, między rzekami Berezówka i Grabówka. Początkowo w Gródku mnisi żyli według reguł agioryckich skitskich monasterów. Zakonnicy mieszkali w swych leśnych celach i tylko w sobotę i niedzielę zbierali się w cerkwi na wspólnych nabożeństwach. Źródła nie wymieniają wezwania świątyni, ale prawdopodobnie była to cerkiew św. Jana Teologa, o której pisze się w Субботнику или Поминнику²3.

Wojna litewsko-moskiewska, prowadzona na początku XVI wieku, przebiegała głównie na wschodnich rubieżach Wielkiego Księstwa Litewskiego, zwłaszcza na Smoleńszczyźnie. Słudzy Chodkiewicza informowali tamtejszego biskupa smoleńskiego Józefa Sołtana o monasterze prawosławnym powstałym nad rzeką Supraśl. Władyka smoleński doskonale zdawał sobie sprawę z rangi powstałego monasteru i kiedy otrzymał w 1504 roku od króla Aleksandra, za zasługi w wojnie z Moskwą oraz utracone majątki, sześć służb kmiecych we włości suraskiej - przekazał je monasterowi ${ }^{24}$. Formalne nadanie nastąpiło 11 maja 1506 roku, kiedy władyka Józef nawiązał bezpośrednie kontakty z Aleksandrem Chodkiewiczem $^{25}$. Na podstawie źródeł trudno jest ustalić, jaką rolę w tych nadaniach odegrał ihumen Pafnucy Sieheń.

$\mathrm{Na}$ pewno przełożony monasteru współpracował z władyką smoleńskim. Prawdopodobnie przy jego pomocy, a może na jego prośbę, biskup Sołtan wraz z ktitorem opracowali nowy regulamin życia w monasterze. Reguła ta zasługuje na szczególną uwagę, ponieważ określała ona zasady wyboru przełożonego monasteru. Nie ktitorzy - jak było powszechnie przyjęte na terenie Wielkiego Księ-

22 АСД, t. IX, s. 2, 42. A. Mironowicz, O poczatkach monasteru supraskiego i jego fundatorach, Supraśl 2013. S. 12-18; Rękopisy supraskie w zbiorach krajowych i obcych, opr. A. Mironowicz, Białystok 2014, s. 11-50.

23 Николай (Далматов), Супрасльский Благовещенский монастырь, s. 6; А. Белецкий, Митрополитъ Іосифъ ІІ Солтанъ и отношение его къ Супрасльскому монастырю, s. 12.

24 „Вестник Западной России”, г. IV, кн. 7, т. III, отд. 2, Вильно 1865/1866, с. 1-6; Hieronim Grala datuje owe wydarzenie na wrzesień 1503 roku, H. Grala, Kotpak Witołdowy czy czapka Monomacha? (Dylematy wyznawców prawosławia w monarchii ostatnich Jagiellonów), [w:] Katolicyzm w Rosji i prawostawie w Polsce (XI-XX w.), Warszawa 1997, przyp. 3, s. 61.

25 Kopia dokumentu por.: AP w Krakowie, AMCh, sygn. 36, nr 29, k. 81-83; АСД, t. IX, s. 6-7; „Вестник Западной России”, г. V, кн. 7, т. I, отд. 2, Вильно 1867, s. 6-9; List króla Aleksandra nadający biskupowi smoleńskiemu Józefowi Sołtanowi dobra Baciuty, Topilec i Piszczewo z 15 września 1504 roku, por. АСД, t. IX, s. 8-9 (wydrukowany z mylną datą roczną). 
stwa Litewskiego - decydowali o wyborze ihumena, a sami zakonnicy. Mnisi wybierali swego przełożonego spośród siebie. Taki sposób wyboru ihumena świadczył o sile i doświadczeniu duchowym zakonników będących w monasterze. Liczba zakonników była duża, a większość z nich musiała mieć długą praktykę życia zakonnego.

Pafnucy Sieheń doprowadził do stworzenia dobrze zorganizowanej wspólnoty zakonnej. Surowe zasady życia w utworzonym monasterze, w zamiarze fundatorów, miały doprowadzić do powstania ośrodka zakonnego, w którym przebywali mnisi o wysokiej moralności, prowadzący ascetyczny tryb życia. Swoją postawą mnisi mieli przyciągnąć do siebie nie tylko prawosławnych, ale i innowierców. Zasady życia w klasztorze, opracowane przez Aleksandra Chodkiewicza i Józefa Sołtana, zostały wysłane do patriarchy Joachima I ${ }^{26} \mathrm{~W}$ celu ich zatwierdzenia. Sam król Aleksander informował patriarchę konstantynopolitańskiego o fakcie założenia przez Aleksandra Chodkiewicza monasteru w swych dobrach - lasach błudowskich, na brzegu rzeki Supraśl. Również właściciel Gródka napisał do patriarchy list, w którym informował adresata o wybudowaniu przez siebie „znamienitej cerkwi” ku czci Bogurodzicy i przekazaniu środków na funkcjonowanie monasteru ${ }^{27}$.

Patriarcha Joachim I z radością przyją̧ wspomniane pisma i podziękował ktitorom monasteru: Aleksandrowi Chodkiewiczowi i biskupowi Józefowi Sołtanowi za ich wysiłki, a następnie przesłał błogosławieństwo klasztorowi i poświęcił go łaską Świętego Ducha. Patriarcha zatwierdził również regułę i zasady życia $\mathrm{w}$ monasterze ${ }^{28}$. W oryginalnym tomosie patriarszym przechowywanym w monasterze supraskim jeszcze w 1867 roku znajdowały się jakże znamienne sformułowania różniące się od kopii spisanej w języku łacińskim.

\footnotetext{
26 Mowa tu o patriarsze konstantynopolitańskim Joachimie I (1498-1502; 1504). Tomos patriarszy został wystawiony prawdopodobnie w 1504 roku, a do monasteru dotarł rok później. Kopia tomosu przechowywana w monasterze posiadała zapewne datę roczną 1505 rok. Por:: АСД, t. IX, s. 3-5; „Вестник Западной России”, г. V, кн. 1, т. I, Вильно 1867, отд. 2, Приложения, s. 1-3; Summariusz dokumentów do dóbr supraskich, s. 54-55, 136.

27 „Вестник Западной России”, г. V, кн. 7, т. I, отд. 2, Вильно 1867, s. 12-14; А. Белецкий, Митрополитъ Іосифъ ІІ Солтанъ и отночение его къ Супрасльскому монастырю, s. 16-17.

${ }_{28} \mathrm{~W}$ dokumencie patriarszym wspomina się o wyborze ihumena przez samych zakonników, zakazie picia alkoholu, nieopuszczania monasteru bez zgody ihumena i przestrzegania postów. „Вестник Западной России", г. V, кн. 7, т. I, отд. 2, Вильно 1867, s. 11; Patriarcha w tomosie z 1505 roku (1504) pisał, że Aleksander Chodkiewicz założył i ufundował za własne środki monaster w swych lasach błudowskich na brzegu rzeki Supraśl monaster „по имени Пречистыя Владичица нашея Богородица, Честнаго Ея Благов'кщенія” і wspomina o wybudowaniu „tej znamienitej cerkwi”, АСД, t. IX, s. 3-5; А. Белецкий, Митрополитъ Іосифъ II Солтанъ и отношение его къ Супрасльскому монастырю, s. 17.
} 
Іоакимъ милостью Божою Архіепискпъ Константинопольский, Новаго Рима вселеньский Патиярх. Понеже славный краль и превеликій князь всей Литвы в своихъ писанихъ показаномъ и нашой сиренности, како маршалокъ его державы Благочестивый и православный и великолепный Панъ Александро, сынъ Пана Ивана Ходкевича, отъ своего имњнія и отъ своего скарбу и отъ своего труда, на своей властной отчизне и дъдине у пущи блудовской у скрай рłки Супраслы, и сфудоменту созида и вънесе честный монастырь по имени Пречистыя Владичица нашея Богородица, Честнаго Ея Благовнщенія. Такъ же своимъ посланіемъ воспомяну намъ той православный Панъ Александро, Еже и сфудоменту воздвигну тую пречистыю обитель, и приложи кней, отъ своее отчизны очемъ бы мkла церково божия на въки стояти, и живушим вней чимъ бы мłли поживитися во славу Христу Богу и родителемъ его впаметь в ъчную. Помеже онъ есть ктиторъ и смирение наше видячи его сердечную любовъ еже имати к Богу, ижъ оть своего труда и оть своего скарбу, постави боголюбезно оть фудомента честыю обитель. За то благославлаемъ ктиторы, Пана Александра і епископа смоленского Іосифа и труды ихъ, да есть жертва ихъ совершена къ Богу, и отъ Господа Бога милости на нихъ да есть всий вњкъ и вбудущий. $(\ldots)^{29}$.

Pafnucy Sieheń zabiegał o zabezpieczenie prawne i materialne swojego monasteru. W Wilnie 26 lutego 1507 roku biskup Józef Sołtan i Aleksander Chodkiewicz uzyskali u króla Zygmunta Starego potwierdzenie nadania monasterowi sześć służb kmiecych, otrzymanych przez władykę smoleńskiego w 1504 roku ${ }^{30}$. Potwierdzenie nadania monasterowi supraskiemu przez władykę smoleńskiego otrzymanych od króla dóbr Topilec, Baciuty i Piszczewo zawierało kilka ważnych informacji. W dokumencie tym wymieniona została jedynie cerkiew Zwiastowania Najświętszej Maryi Panny położona na skraju rzeki Supraśl w ojczyźnie Aleksandra Chodkiewicza. Czy byłoby możliwe wybudowanie cerkwi na uroczysku Suchy Hrud już w 1506 roku? Autor Kroniki Ławry Supraskiej uważał to za niemożliwe.

Cerkiew murowana, pisze $\mathrm{w}$ pominniku, że stanęła za pierwszego archimandryty Siehenia przez lat trzy, co się stać nie mogło w tak prędkim czasie, bo przeniosszy się z Gródka na te miejsce w roku 1500, i zastawszy tylko puszczę, trzeba było najprzód cegielnię, etc. ufundować, gliny nakopać, wapna przysposobić; a i cegła czasu nie mało weźmie na taką strukturę, zaczym moim zdaniem, mogła się zacząć za pierwszego archimandryty, a za drugiego Kaliksta zakończona jest, i pewna że kosztem fundatorskim, bo jeszcze przy początkach klasztor jakby nic nie miał ${ }^{31}$.

29 „Вестник Западной России”, г. V, кн. 1, т. I, отд. 2, Приложения, s. 3.

30 AP w Krakowie, AMCh, sygn. 36, nr 29, k. 83-84; АСД, t. IX, s. 22-24. Regest tego dokumentu wskazuje, że wydanie nastąpiło 17 lipca 1507 roku. Prawa i przywileje miasta $i$ dóbr ziemskich Zabłudów XV-XVIII w., oprac. J. Maroszek, Białystok 1994, s. 86.

${ }^{31}$ АСД, t. IX, s. 25. 
Z pewnością Mikołaj Radkiewicz nie miałby takich wątpliwości co do czasu budowy cerkwi Zwiastowania Najświętszej Maryi Panny, gdyby założył, że informacje podane w Субботнику или Поминнику dotyczą wielkiej świątyni wybudowanej na terenie pierwotnej lokalizacji monasteru, prawdopodobnie wykonanej z drewna ${ }^{32}$.

W dokumencie z 11 maja 1506 roku nie wymienia się lokalizacji monasteru i cerkwi Zwiastowania Najświętszej Maryi Panny, a jedynie ihumena Pafnucego. Biskup Józef Sołtan zobowiązał Aleksandra Chodkiewicza, marszałka hospodarskiego, namiestnika puńskiego, do opieki nad nadanymi monasterowi dobrami i obrony klasztoru przed wszelkimi krzywdami.

Нижли в опеку и от кривд боронити того именья и людей и земли полецаю и приказую пану Александру Ивановичу Ходкевичы, и по нем его детем и его счадком и их бояром и слугам, для того, иж тот монастырь у его отчизне стоит. Понеж они суть ктиторы того монастыря, они мают от всих кривд боронити $(\ldots)^{33}$.

W lutym 1507 roku Józef Sołtan „nareczenyj”34 metropolitą wsparł starania mnichów o nową lokalizację monasteru. W 1507 roku hierarcha poparł u Aleksandra Chodkiewicza prośbę ihumena Pafnucego i mnichów o przeniesienie monasteru z Gródka na nowe miejsce. Władyka doskonale znał z autopsji sytuację klasztoru i przekonał białoruskiego magnata do wyrażenia zgody na nową lokalizację monasteru. Analizując pierwsze zapisy Aleksandra Chodkiewicza, odnośnie udostępnienia lasu do budowy nowych budynków klasztornych, można wnioskować, że pierwsze zabudowania na uroczysku Suchy Hrud były drewniane. Wkrótce jednak powstała myśl o budowie cerkwi z kamienia. Wobec panującego na terenie Wielkiego Księstwa Litewskiego oficjalnego zakazu budowy cerkwi murowanych, wymagana była zgoda królewska na wzniesienie takiej świątyni. Ihumen Pafnucy Sieheń wystąpił z taką prośbą do króla na początku 1509 roku. W połowie marca 1509 roku Zygmunt Stary wyraził zgodę na wybudowanie murowanej cerkwi.

Бил нам челом игумен Супрасльскій Пафнутій о том, чтож он працою своею... (...) будовати монастырь в пущи пана Александра Ходкевича на реце Супраслы и просил нас о том, чтоб дозволили церковь и монастырь муровати. Ино мы з ласки нашое на его чолобите дозволили ему церковь и монастырь

32 Szerzej o tym por.: A. Mironowicz, O poczatkach monasteru supraskiego i jego fundatorach, s. 19-24.

33 AP w Krakowie, AMCh, sygn. 36, nr 29, k. 80-82, 129-134; АСД, t. IX, s. 6-7.

34 „Нарєчєнный” („Nareczenyj”) - nazwany, mianowany, posiadający nadaną godność, stanowisko. 
муровати в той пущи пана Александра Ходкевича, где ся будет видеть ему угодно будовати ${ }^{35}$.

Dopiero po uzyskaniu takiej zgody ihumen Pafnucy mógł przystąpić do zaplanowanej inwestycji. Budowę świątyni rozpoczęto w październiku 1510 roku. W 1509 roku i w pierwszych dziewięciu miesiącach roku następnego gromadzono materiały. W połowie października 1510 roku metropolita Józef odwiedził monaster. Z nadania Aleksandra Chodkiewicza wynika, że metropolita przebywał „у монастыри на реке Супраслы”з6. 15 października 1510 roku metropolita w swym przywileju pisze, że „нашею доброю волею и накладом соружити монастырь иноком общаго равножительства у пана Александра Ивановича Ходкевича, у отчизной пущи Блудовской, на край реки Супраслы, на острове межи источников водных - речок Грабовки и Березовки"з7.

Już wkrótce po podjęciu decyzji o przeniesieniu Aleksander Chodkiewicz po raz drugi potwierdził przekazanie w 1501 roku monasterowi w Choroszczy: „с всем правом и панством, ни чого не оставляючи на себе и наши наследники". Potwierdzenie nadania Choroszczy było potrzebne z uwagi na nową lokalizację monasteru. Chodkiewicz potwierdził zasady wyboru ihumena, zachowując sobie jedynie prawo usunięcia go z monasteru, jeśli będzie prowadzić życie niezgodne ze statutem klasztornym. Magnat wzywał ihumena do troski o majątek monasterski oraz zobowiązywał się do obrony jego ziem i dóbr ${ }^{38}$.

35 AP w Krakowie, AMCh, sygn. 36, nr 29, k. 1; Николай (Далматов), Супрасльский Благовещенский монастырь, s. 45; А. Белецкий, Митрополитъ Іосифъ II Солтанъ и отношение его къ Супрасльскому монастырю, s. 21; Модест (Стрельбицкий), Супрасльский Благовещенский монастырь, с. 75; Ф. Покровский, Археологическая карта Гроденской губерни, Вильна 1895, s. 72; Summariusz dokumentów do dóbr supraskich, s. 55.

36 Dokument jest wystawiony z datą 13 października 1510 roku. АСД, t. IX, s. 13-16; „Вестник Западной России", г. IV, кн. 7, т. III, отд. 1, Вильно 1866, s. 9-14. Po gruntownej analizie dokumentu i z uwagi na fakt, że Aleksander Chodkiewicz znajdował się w więzieniu, niesłusznie posądzony o udział w spisku księcia Michała Glińskiego, od lutego 1509 do 10 maja 1511 roku należy uznać, że nadania monasterowi supraskiemu miały miejsce w 1511 roku, a nie jak wydano drukiem w 1510 roku. Dokument pergaminowy z datą 13 października 1510 roku. Por.: Biblioteka Muzeum Narodowego im. Czartoryskich w Krakowie, Zbiór dokumentów pergaminowych, nr MNK $541 / 1$.

37 Николай (Далматов), Супрасльский Благовещенский монастырь, s. 19-23; А. Белецкий, Митрополитъ Іосифъ II Солтанъ и отношение его къ Супрасльскому монастырю, s. 22.

38 Документы относящихся к истории Супрасльского монастыря, „Вестник Западной России", кн. 7, т. II, отд. 2, Вильно 1861. Choroszcz trafiła do Chodkiewiczów po 1470 roku, a przed 1483 rokiem i do założenia zamku w Gródku stanowiła centrum dóbr Iwana i Aleksandra Chodkiewiczów. J. Wiśniewski, Początki Biategostoku i okolicznego osadnictwa, [w:] Studia i materiały do dziejów miasta Białegostoku, t. IV, Białystok 1985, s. 7-27; H. Surynowicz, Pod opiekq Matki Bożej. Dzieje parafii prawosławnej w Choroszczy, Choroszcz 2008, s. 21. W Kronice Ławry Supraskiej dokument ten jest datowany na 13 października 1510 roku. АСД, t. IX, s. 13-16; Акты, относящиеся к истории Южной и Западной России, собранные и изданные 
Z powyższych zapisów wynika, że Pafnucy Sieheń miał pełne poparcie ktitorów i zabezpieczenie materialne przy realizacji budowy cerkwi Zwiastowania Najświętszej Maryi Panny. Wkrótce pozycja ihumena w monasterze ulegnie zasadniczej zmianie.

W przypadku zabezpieczenia materialnego monaster od swego założenia do połowy XVI wieku otrzymywał liczne nadania i zapisy. Klasztor wszedł w posiadanie wielu ziem i majątków: dworu i miasta Choroszcz, dóbr Chworostowo i Pużycze na Polesiu, Fast, Porosł i Klewinowa na Podlasiu oraz nadanych przez metropolitę Józefa Sołtana wsi: Topilec, Baciuty, Piszczewo ${ }^{39}$, ziemi nad rzeczką Biały Stok ${ }^{40}$, ziemi Uboczowszczyzna ${ }^{41}$, sianożęć w Karaku-

Археографической комиссиею, t. I, Санкт-Петербург 1863, s. 40-42 (dalej: АЮЗР); Акть, издаваемые Виленскою Археографическою Комиссиею, высочайше уирежденною для разбора древних актов в Вильне (dalej АВАК), t. VI, Вильно 1872, s. 3. Krytyczne wydanie dokumentu por.: Prawa i przywileje miasta i dóbr ziemskich Zabłudów XV-XVIII, opr. J. Maroszek, Białystok 1994, s. 37-45. Zapis fundacyjny Choroszczy dla monasteru supraskiego nastąpił 25 maja 1501 roku. AP w Krakowie, AMCh, sygn. 36, nr 29, k. 65-71; Николай (Далматов), Супрасльский Благовещенский монастьрь, s. 488-490. W 1507 roku król nadał Choroszczy prawa magdeburskie i potwierdził wolę Aleksandra Chodkiewicza, „Słownik Geograficzny Królestwa Polskiego i innych krajów słowiańskich", t. I, Warszawa 1880, s. 633; АСД, t. IX, s. 14-16, 22-25; Sumariusz dokumentów dóbr supraskich, t. II, s. 130-131; Николай (Далматов), Супрасльский Благовещенский монастырь, s. 15-18. Konfirmacja przywileju Aleksandra Chodkiewicza z datą 13 października 1510 roku dana na rzecz monasteru supraskiego dokonana 31 stycznia 1623 roku przez króla Zygmunta III Wazę, por.: AP w Krakowie, AMCh, sygn. 36, nr 29, k. 3, (mikrofilm J-14603), s. 65-72 (s. 66).

39 АСД, t. IX, s. 8-9. Król potwierdził nadania metropolity Józefa Sołtana 11 maja 1506 roku. Lietuvos Metryka. Knyga nr 25 (1387-1546). Užrašymu knyga 25, Vilnus 1998, nr 220-222, s. 273-276. Potwierdzenie nadań Aleksandra Chodkiewicza dóbr Choroszcz na rzecz monasteru supraskiego i Józefa Sołtana na wsie Topilec, Baciuty i Piszczewo przez króla Zygmunta Starego nastąpiło 17 lipca 1507 roku. АСД, t. IX, s. 22-24. W granicach uposażenia monasteru znajdowało się sześć wsi: Topilec, Baciuty, Zawady, Zaczerlany, Kościuki i Gajewniki. Uposażenie obejmowało tereny obfitujące w lasy i rzeczki, a przez rzekę Narew miało doskonałe połączenie z Choroszczą. Dobra te stanowiły główne zaplecze materialne monasteru i gwarantowały jego rozwój. Zygmunt Stary 23 października 1529 roku potwierdził nadanie przez Aleksandra Chodkiewicza dóbr Chworostowo i Pużycze na Polesiu oraz wsi Fasty, Porosły i Klewinowo na Podlasiu na rzecz monasteru supraskiego. АСД, t. IX, s. 40-41; АВАК, t. I, Вильно 1865, s. 46-49.

40 Na początku monaster supraski, oprócz pasu puszczańskiego między rzekami Grabówką i Brzozówką i dobrami choroskimi, posiadał ziemie sięgające do Białego Stoku, przez zakupienie od „ludzi królewskich pasa łąk”. Ziemie te były obiektem konfliktów między monasterem a właścicielem dóbr białostockich Mikołajem Michnowiczem Raczkiewiczem. Drugim obszarem spornym były ziemie nabyte przez mnichów supraskich od Onisima Jakowlewicza Wyporadkowicza, na które Mikołaj Michnowicz otrzymał w 1509 roku również przywilej. Biblioteka Akademii Nauk w Wilnie, F 16 (B2), nr 134, k. 12v. Ugoda między Mikołajem Michnowiczem a ihumenem supraskim 14 grudnia 1514 r. Por.: druk z inną datą dzienną - 11 grudnia. АСД, t. IX, s. 32-34; AP w Krakowie, AMCh, sygn. 35, k. 1-8; M. Łozowska, Fundacja klasztoru supraskiego w pierwszej potowie XVI wieku. Próba interpretacji dokumentów uposażeniowych, [w:] Małe miasta. Historia i wspótczesność, t. I, Supraśl 2001, s. 52-53; Summariusz dokumentów do dóbr supraskich, s. 58.

41 Biblioteka Muzeum Narodowego im. Czartoryskich w Krakowie, Zbiór dokumentów pergami- 
łach ${ }^{42}$. Sam ihumen Pafnucy dokonywał licznych zakupów ziemi, powiększając tym samym stan posiadania klasztoru. Do monasteru należały ziemie pomiędzy rzeczkami Biały Stok i Supraśl, liczne bartnie i jazy oraz inne dobra. Ziemie te ihumen Pafnucy zakupił m.in. od Onisima Jakowlewicza Wyporadkowicza ${ }^{43}$ i Maksyma Kosteniewicza ${ }^{44}$.

Za czasów Pafnucego Siehenia monaster nad rzeką Supraśl otrzymał specjalną patriarszą opiekę, a jego ihumen był tytułowany „игуменом Благовещенской патріяшей обители", czyli ihumenem monasteru patriarszego Zwiastowania Najświętszej Maryi Panny. Trudno znaleźć powód takiego uznania przez patriarchę konstantynopolitańskiego dla nowo powstałego monasteru. Na pewno do objęcia patronatem patriarszym nie wystarczyły jedynie prośby jego ktitorów.

Udział ihumena Pafnucego w soborze lokalnym w Wilnie miał istotne znaczenie dla niego samego i monasteru. Sobór w Wilnie, odbywający się na przełomie 1509 i 1510 roku, ustanowił piętnaście zasad, które miały regulować relację między władzą duchowną a świecką. Celem ich było osłabienie wpływu świeckich na obsadzanie stanowisk cerkiewnych i podniesienie prestiżu władzy duchownej. Podczas obrad podjęto postanowienia dotyczące stosunku duchowieństwa do władzy świeckiej, określono sposób wyłaniania kandydatów na stanowiska kościelne, regulowano życie kleru i kwestie sądownictwa duchownego ${ }^{45}$.

Na soborze wileńskim omawiano sprawę monasteru supraskiego, który uzyskał potwierdzenie swej pozycji na mocy specjalnego tomosu od patriarchy konstantynopolitańskiego Joachima ${ }^{46}$. Nic też dziwnego, że na soborze ojciec Pafnucy był wymieniany jako pierwszy po przełożonym Ławry Kijowsko-Pieczer-

nowych, nr 860, t. I, k. 13; Summariusz dokumentów do dóbr supraskich, s. 58.

42 АСД, t. IX, s. 26.

43 Kopia dokumentu króla Aleksandra z 28 lipca 1505 roku potwierdzającego kupno przez ihumena Pafnucego ziemi i sianożęci w Bokinie od Onisima Jakowlewicza Wyporadkowicza. АСД, t. IX, s. 27; „Вестник Западной России”, г. V, кн. 4, т. III, Приложения, s. 6-7; „Вестник Западной России", г. V, кн. 7, т. I, отд. 2, Вильно 1867, s. 15; Zakup przez mnichów supraskich terenów pomiędzy rzekami Biały Stok i Supraśl a drogą z Dojlid do Jurowiec od bojarów Wyporadkowiczów został dokonany prawdopodobnie w 1500 roku. Por.: J. Maroszek, Rewelacyjne odkrycie nieznanych najstarszych dokumentów dla Białegostoku, „Białostocczyzna” 1999, nr 1, s. 22-23.

44 AP w Krakowie, AMCh, sygn. 36, nr 29, k. 3; „Вестник Западной России”, г. V, кн. 4, т. III, s. 5-6; „Вестник Западной России”, г. V, кн. 7, т. I, отд. 2, Вильно 1867, s. 15; Summariusz dokumentów do dóbr supraskich, s. 55, 66; H. Surynowicz, Pod opieka Matki Bożej, s. 26-27.

45 „Русская Историческая Библиотека”, t. IV, s. 5-18; A. Mironowicz, Kościót prawostawny w państwie Piastów i Jagiellonów, Białystok 2003, s. 223, 225.

46 Mowa tu o patriarsze konstantynopolitańskim i ekumenicznym Joachimie I (1498-1502; 1504-1505). Por. Археографический сборник документов, относящихся к истории Северо-Западной Руси, издаваемый при управлении Виленского учебного округа (dalej: АСД), t. IX, Вильно 1870, s. 3-5; „Вестник Западной России. Историко-литературный журнал”, Вильно 1867, г. V, кн. VII, т. I, Приложения, s. 1-3; Summariusz dokumentów do dóbr supraskich, opr. A. Mironowicz, Białystok 2009, s. 54-55, 136. Митрополит Макарий, История 
skiej Jonaszu ${ }^{47}$. Monaster nad rzeką Supraśl podlegał bowiem jedynie patriarsze konstantynopolitańskiemu ${ }^{48}$.

Na soborze wileńskim (1509-1510 rok) zapadła też decyzja o wyborze ihumena supraskiego, Pafnucego Siehenia na biskupa. Kilku ordynariuszy było już w podeszłym wieku, zwłaszcza władyka włodzimiersko-brzeski Wassian II, dlatego ihumen Pafnucy, według metropolity Józefa Sołtana, był najlepszym kandydatem na stanowisko ordynariusza tej diecezji. Ihumen supraski został więc biskupem „nareczenym”, ale godność swoją objął po śmierci władyki Wassiana II. Jego kandydaturę poparł nie tylko metropolita Józef, ale i świeckie elity prawosławne: książę Fiodor Jarosławowicz, książę Konstanty Ostrogski, księżna Helena i Aleksander Chodkiewicz ${ }^{49}$.

Po wyborze ihumena Pafnucego na biskupa włodzimiersko-brzeskiego 15 października 1510 roku metropolita Józef Sołtan nadał nowy „ustaw”, regułę klasztorną, którą powinni przestrzegać zakonnicy ${ }^{50}$. Zbieżność czasowa owych dwóch wydarzeń wskazuje, że obaj hierarchowie pragnęli zachować kontrolę nad rozwijającym się monasterem. Nowy ihumen w świetle nowego „ustawu” nie miał już takich praw jak Pafnucy Sieheń. Ihumen został zobowiązany do nieopuszczania monasteru bez szczególnej przyczyny. Na spotkanie z królem czy ktitorem ihumen mógł wyjechać jedynie w towarzystwie dwóch zakonników wybranych przez starszyznę monasterską. Po załatwieniu spraw przełożony powinien bez zwłoki wrócić do monasteru. Sprawy gospodarcze ihumen miał rozstrzygać razem z klasztornym ekonomem oraz wybranymi do tego zadania mnichami. Wszelkie pieniądze wpływające do monasteru miały być przechowywane przez ekonoma i wyznaczonych mnichów w skarbcu cerkiewnym. Oni też powinni

Русской Церкви, t. IX, Санкт-Петербург 1879, s. 168; Акты исторические собранные и изданные Археографической комиссиею, t. I, Санкт-Петербург 1841, s. 524-529, АСД, t. IX, s. 5. Oryginał jest przechowywany w: AP w Krakowie, AMCh, sygn. 36, nr 29; „Вестник Западной России”, г. V, кн. 7, т. I, отд. 2, s. 15; Summariusz dokumentów do dóbr supraskich, s. 57, 139; Николай (Далматов), Супрасльский Благовещенский монастырь, s. 24-27.

47 Макарий, op. cit., t. IX, Санкт-Петербург 1879, s. 168; Актьл исторические собранные и изданные Археографической комиссиею..., t. I, Санкт-Петербург 1841, s. 524-529. Na ten przywilej patriarszy powoływał się metropolita kijowski Józef Sołtan w 1514 roku. АСД, t. IX, s. 5. Oryginał jest przechowywany w Archiwum Państwowym na Wawelu, Archiwum Młynowskie Chodkiewiczów (dalej: AP w Krakowie, AMCh), nr 36; „Вестник Западной России”, Вильно 1867, г. V, кн. VII, т. I, s. 15; Summariusz dokumentów do dóbr supraskich..., s. 57, 139.

48 А. Белецкий, Митрополитъ Іосифъ II Солтанъ и отношение его къ Супрасльскому монастырю, Вильна 1899, s. 16-17; A. Mironowicz, O początkach monasteru supraskiego i jego fundatorach..., s. 34-35.

49 A. Mironowicz, Sobory wileńskie 1509 i 1514 roku, [w:] Synody Cerkwi prawosławnej w I Rzeczypospolitej, (red.) M. Kuczyńska i U. Pawluczuk, „Latopisy Akademii Supraskiej”, t. 5, Białystok 2014, s. 71-82.

$50 \mathrm{Na}$ temat reguł życia wewnętrznego w monasterach, por.: Древнерусские иноческие уставы, подг. текста, Т. В. Суздальцева, Москва 2001 (Русский типик); Монашество и монастыри в России XI-XX вв: исторические очерки, отв. ред. Н. В. Синицына, Москва 2002. 
prowadzić szczegółowy rejestr dochodów i wydatków monasterskich i składać coroczne sprawozdanie ihumenowi o stanie finansów. Ihumen powinien nadzorować zachowanie braci, którzy mieli żyć w „miłości i posłuszeństwie”. Wszelkie naruszenie zasad życia klasztornego było napominane, a gdy owe napomnienia nie skutkowały, osobę taką usuwano z monasteru ${ }^{51}$.

„Ustaw” ten określał rolę monasteru w ówczesnej Cerkwi. Metropolita pragnął, ażeby klasztor przez surową regułę życia wewnętrznego wzbudzał respekt wśród prawosławnych i innowierców. Mnisi mieli umacniać wiarę wśród prawosławnych mieszkańców zachodnich obszarów Wielkiego Księstwa Litewskiego, a wśród innowierców rozwijać szacunek wobec Cerkwi. W „ustawie” zwraca uwagę zapis odnośnie celi zakonnej. Mogły w niej być przechowywane jedynie ubrania, księgi i rzeczy niezbędne do pracy monasterskiej. Metropolita Józef znał skład osobowy zgromadzenia i wiedział, że wśród mnichów znajduje się wiele osób wykształconych - umiejących czytać i pisać, kopiować i interpretować teksty liturgiczne.

Powstaje pytanie - po co nadano klasztorowi nowy statut, skoro monaster posiadał go już wcześniej, a patriarcha konstantynopolitański Joachim zatwierdził regułę specjalnym ,tomosem” z 1505 roku? Nowy statut ustalał zasady życia wspólnotowego na terenie nowej lokalizacji monasteru. Wcześniejsze regulacje odnosiły się do życia eremickiego, które mnisi prowadzili w okolicy Gródka. Należy zwrócić uwagę na surowość pierwszej reguły życia monastycznego w Supraślu. Wielu mnichów przeszło wszystkie stopnie życia zakonnego i stało się schimnikami. Wśród nich było kilku otszelników (pustelników), żyjących w osobnych leśnych celach poza monasterem. Zmiana lokalizacji klasztoru spowodowała nie tylko zmianę charakteru życia monastycznego z eremickiego (anachoretycznego) na wspólnotowe (cenobityczne), ale skutkowała również odejściem części mnichów do Ławry Kijowsko-Pieczerskiej i na św. Górę Athos. Wśród tych ostatnich był św. męczennik Antoni Supraski, który przybył z imieniem Onufry do monasteru supraskiego na początku XVI wieku i oddał się pod duchową opiekę,

\footnotetext{
51 Według tego „ustawu” bracia powinni przebywać w monasterze, a ich wyjścia w sprawach klasztornych na zewnątrz mogły się dokonać jedynie za zgodą ihumena, w towarzystwie dwóch lub trzech mnichów. Mnisi nie mogli mieć własnych rzeczy (ubrania, jedzenia, pościeli). Wszystko zakonnik otrzymywał od monasteru. Nawet ihumen jadł w sali jadalnej (trapiezie), z wyjątkiem nadzwyczajnych okoliczności. Ihumen i hieromnisi mogli nosić habity (rasy) z czeskiego sukna, pozostali zaś ze zwykłego. W celach zakonnych mogło znajdować się jedynie ubranie i książki. Zakonnicy w poniedziałek, środę i piątek jedli tylko raz dziennie. Głównym składnikiem pożywienia w te dni był chleb i woda. We wtorek mnisi spożywali pokarm dwukrotnie w dzień, ale bez oleju, a w czwartek z olejem. Napojami mnichów była woda i kwas. Do monasteru przyjmowano wszystkich prawosławnych mężczyzn, ale zaliczenie do grona braci zakonnej następowało dopiero po trzymiesięcznym lub sześciomiesięcznym nowicjacie. Mnisi z innych klasztorów, za zgodą ihumena, mogli wstąpić do wspólnoty po trzydniowym pobycie w monasterze. Dzieci nie przyjmowano do monasteru, a kobietom było zabronione wejście na jego teren. АСД, t. IX, s. 16-19; „Вестник Западной России”, кн. 8, т. III, отд. 2, Вильно 1866, s. 1-6.
} 
powszechnie szanowanego, ihumena Pafnucego. Po kilku latach pobytu w klasztorze mnich Onufry przyjął wielką schimę z nowym imieniem Antoni i poprosił ihumena Pafnucego o zgodę na udanie się na św. Górę Athos, do krajów okupowanych przez Turków, ażeby oddać życie za Chrystusa. Antoni opuścił monaster supraski przed końcem 1510 roku, kiedy ihumen Pafnucy był jeszcze jego przełożonym. Męczeńska śmierć mnicha Antoniego nastąpiła w Salonkach w 1516 roku $^{52}$.

„Ustaw” metropolity Józefa z 15 października 1510 roku nic nie wspominał o wybudowanej murowanej cerkwi. Oznacza to, że dopiero po tej dacie rozpoczęto bądź kontynuowano budowę cerkwi Zwiastowania Najświętszej Maryi Panny. Nie wiadomo, czy na terenie Suchego Hrudu znajdowały się wówczas inne budowle. Według Aleksego Bieleckiego, który zapoznał się z oryginalnym dokumentem „ustawu”, nie było w nim żadnej informacji o świątyniach, a dopiero do późniejszej kopii wstawiono o nich odpowiedni zapis ${ }^{53}$. Przywilej metropolity rozpoczynał się od sformułowania, że Aleksander Chodkiewicz postanowił „доброю волею и накладом сооружити монастырь иноком мнишскаго общаго равножительства" w dobrach swoich na uroczysku między dwiema rzekami Grabówka i Berezówka. Nastąpiło to latem 1510 roku za panowania króla Zygmunta Starego, przy metropolicie kijowskim Józefie Sołtanie, w dobrach rodowych Aleksandra Chodkiewicza.

Z tym opisem koresponduje wstawione do ,ustawu” monasterskiego opowiadanie o powstaniu świątyń klasztornych:

И наперве соружена бысть церковь невелика, теплая, во имя святаго Іоанна Богослова, и трапеза на прихожденіе братіи. И освещена бысть тая церковь преосвященным митрополитом Кіевским и всея Руси Іосифом, на Обретеніе святыя главы Предтечи и Крестителя Іоанна, мая 25 день, индикт 14. И потом соружена бысть великая церква Пречистыя Богоматере, Честнаго Ея Благовещенія, с приделы святых мученик Бориса и Глеба, нареченных в святом крещеніи Романа и Давида, и святых преподобных отец Печерских Антонія и Феодосія. Сія же святыя Божія церкви освященны бышя преосвященным митрополитом Кіевским и всея Руси. В честь и хвалу и славу и поклоненіе и пеніе Вседержительной, Единосущней Троицы Отцу и Сыну и Святому Духу, Единому Богу, сбранным, живущим в сей святей Лавре, посполито всему, еже

52 А. А. Турилов, Антоний Супрасльский, „Православная энциклопедия”, t. II, Москва 2001, s. 680; tenże, Житие преподобномученика Антония Супрасльского и славянские жития балканских новомучеников XVI в. (к постановке проблемы), Hagiographia Slavica, (red.) von J. Reinhart, Munchen-Berlin-Wien 2013, (,Wiener Slawistischer Almanach. Sonderband”. Bd. 82),

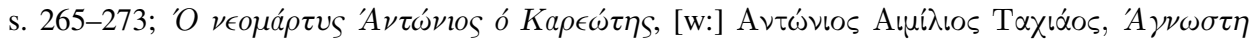

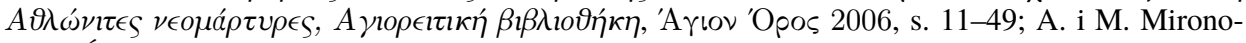
wicz, Św. Antoni Supraski, Białystok 2014.

53 А. Белецкий, Митрополитъ Іосифъ II Солтанъ и отношение его къ Супрасльскому монастьию, s. 25. 
о Христе братству обще вкупе живущим на отпущеніе грехов и на спасеніе душам, а отшедшим от телес душам в наследіе царства небеснаго, его же Господь Бог сподобит и нас всех получити о Христе Іисусе Господе нашем, Ему же слава в веки, аминь.

$\mathrm{W}$ tej relacji znajduje się kolejna istotna informacja: „И помовивши о том с сыном нашим паном Александром Ивановичом Ходкевичом и с всим, еже о Христе братсвом, хотячи утвержденіе мети общему жительству по уставу божественнаго писанія, добровольне единоумно завет положихом" ${ }^{54}$. Dalej następuje podanie ,ustawu” monasterskiego. Zwróćmy uwagę na fakty we wstawionym, dopisanym później fragmencie, przed treścią podanych reguł klasztornych. Przywilej metropolity Józefa został rzekomo wstawiony 15 października 1510 roku, a więc nie mógł podawać faktów po tej dacie. Między innymi w dokumencie mówi się o wyświęceniu cerkwi św. Jana Teologa 25 maja, indykta 14, to jest 25 maja 1511 roku. Przypomnę, że indykta rozpoczynają się 1 września, a kończą się 31 sierpnia następnego roku. Jakim więc sposobem metropolita mógł napisać, co się wydarzy 25 maja 1511 roku? W dokumencie mówi się о „живущим” w Lawrze, a więc tam, gdzie monaster funkcjonuje, a nie dopiero się buduje. W „ustawie” metropolita Józef Sołtan pisze o sobie w pierwszej osobie, a we fragmencie opowieści o powstaniu cerkwi klasztornych mówi się o metropolicie w osobie trzeciej. Z dopisku tego wynika, że nowa cerkiew św. Jana Teologa na uroczysku Suchy Hrud została wyświęcona 25 maja 1511 roku. Wszystko staje się zrozumiałe, kiedy przyjmiemy, że do oryginalnego dokumentu - przywileju Józefa Sołtana z 1510 roku, któryś z mnichów, w późniejszym czasie, dodał informację o budowie świątyń klasztornych. Przywołując tu zapisy z Субботника или Поминника mоżna też wnioskować, że niektóre informacje o cerkwiach dotyczą pierwotnej lokalizacji monasteru w Gródku. Mnisi wielokrotnie dokonywali dopisków do oryginalnych dokumentów w różnych polach. Pewną podpowiedzią, kiedy pobudowano monaster na uroczysku Suchy Hrud może być przywilej metropolity Józefa Sołtana dany klasztorowi 5 lutego 1514 roku, gdzie mówi się o supraskim monasterze, który „stał nowo” i nazywa się go „новосооружоным” 55 .

Wynika z tego, że ihumen Pafnucy Sieheń rozpoczął budowę cerkwi, ale jej nie zakończył. Jako „nareczenyj” biskup włodzimiersko-brzeski od 1511 roku

\footnotetext{
54 АСД, t. IX, s. 17; A. Mironowicz, Powstanie monasteru supraskiego, s. 25.

55 Biblioteka Muzeum Narodowego im. Czartoryskich w Krakowie, Zbiór dokumentów pergaminowych, nr 76, (MNK 541/8), k. 1; Николай (Далматов), Супрасльский Благовещенский монастырь, s. 28. „Бо тая обитель стала на нове, предъ тымъ издавна съ того месца митрополитомъ продкомъ нашимъ никакихъ пожитковъ небывало". АВАК, Акты Гродненского земского суда, t. I, Вильно 1865, s. 38; „Вестник Западной России”, г. VIII, кн. 2, т. I, отд. 2, Вильно 1870, s. 19-24.
} 
nie przebywał już w monasterze, a prawdopodobnie w Brześciu. Władyka Pafnucy pozostawił monaster $\mathrm{w}$ bardzo dobrym stanie duchowym i materialnym. Kilkudziesięciu mnichów z dużym stażem życia monastycznego gwarantowało stabilność ośrodka zakonnego. Szeroko podjęte inwestycje, zgromadzenie bogatej kolekcji ksiąg rękopiśmiennych, rozpoczęcie budowy cerkwi Zwiastowania Najświętszej Maryi Panny były możliwe do zrealizowania dzięki pozyskaniu przez Pafnucego licznych nadań i zapisów ówczesnych elit prawosławnych, takich jak: księżna Helena, Aleksander Chodkiewicz - marszałek hospodarski (1506-1509), Iwan Sapieha - wojewoda podlaski, czy Józef Sołtan - metropolita kijowski ${ }^{56}$.

\section{Pafnucy - biskup włodzimiersko-brzeski}

Pafnucy, po wyborze na soborze wileńskim w 1510 roku na biskupa włodzimiersko-brzeskiego, przebywał w monasterze supraskim do końca tego roku. Po wyborze Kaliksta na ihumena Pafnucy opuścił klasztor i udał się do Włodzimierza, gdzie przebywał przez następny rok, jako „narieczennyj” władyka. Jest więc prawdopodobne, że jako „narieczennyj” władyka Pafnucy w latach 1511-1512 przebywał w Brześciu, zarządzając tą częścią diecezji włodzimiersko-brzeskiej i pomagał pozostającemu w podeszłym wieku biskupowi Wassianowi II. Nie była to obca diecezja dla władyki Pafnucego. Bielsk, z którego pochodził, należał do eparchii włodzimiersko-brzeskiej i wszelkie sprawy tego biskupstwa były mu znane ${ }^{57}$.

Diecezja włodzimiersko-brzeska coraz bardziej ulegała podziałowi na dwie części: brzeską i włodzimierską. Nastąpiło to już w czasach Kazimierza Wielkiego, kiedy król opanował ziemie położone wzdłuż Prypeci, odcinając Włodzimierz od Brześcia. Granica państwowa polsko-litewska w tym regionie ukształtowała się dopiero w drugiej połowie XV wieku. Fakt ten miał istotne konsekwencje do ukształtowania się obszaru diecezji włodzimiersko-brzeskiej. Część terytorium tego biskupstwa, należąca do Wielkiego Księstwa Litewskiego, została

56 Николай (Далматов), Супрасльский Благовещенский монастьрь, s. 62. O nadaniach księżnej Heleny monasterowi supraskiemu por.: Prawa i przywileje miasta i dóbr ziemskich Zabłudów $X V-X V I I I$ w., oprac. J. Maroszek, Białystok 1994, s. 42, przyp. 4.

57 Struktura terytorialna diecezji prawosławnych ustaliła się już w XIV wieku, ale granice zmieniały się również w następnych stuleciach. Granice biskupstw pierwotnie były zgodne z granicami państwowymi i administracyjnymi wewnątrz państwa. Rekonstrukcja granicy między biskupstwem metropolitalnym i włodzimiersko-brzeskim na Podlasiu potwierdza owe spostrzeżenia. W przypadku diecezji włodzimiersko-brzeskiej decydującym czynnikiem określającym jej terytorium była zmieniająca się przynależność państwowa i administracyjna poszczególnych części eparchii. Ukształtowany w ten sposób obszar eparchii włodzimiersko-brzeskiej przetrwał do końca XVI wieku. Por.: A. Mironowicz, Podlaskie ośrodki i organizacje prawostawne w XVI i XVII w., Białystok 1991, s. 66-70. 
oddzielona przez zabużańską część eparchii chełmskiej, pozostającej w granicach Korony Polskiej. Przynależność do dwóch państw spowodowało pogłębienie się podziału diecezji na dwie części: brzeską i włodzimierską. Podział terytorialny północnej części diecezji i odcięcie jej od Włodzimierza Wołyńskiego doprowadziły do powstania we Włodzimierzu i w Brześciu dwóch ośrodków duchownych, zarządzających poszczególnymi częściami diecezji. Oficjalnie więc biskupi włodzimierscy zaczęli tytułować się jako włodzimiersko-brzescy od 1405 roku. W drugiej połowie XV wieku w Brześciu na stałe przebywał namiestnik biskupa włodzimierskiego i kłyros. Kłyros był organem władzy administracyjnej i sądowniczej diecezji (od greckiego słowa kléros 'duchowieństwo katedralne'). Kłyrosy znajdowały się wyłącznie w stolicach diecezji. W skład kłyrosu wchodzili prezbiterzy cerkwi parafialnych miasta stołecznego biskupstwa. Na ich czele stał protoprezbiter, zwany często protopopem. Do obowiązków kłyroszan należało odprawianie nabożeństw i pełnienie funkcji duszpasterskich w cerkwi katedralnej oraz asystowanie biskupowi w jego obowiązkach religijnych. Członkowie kłyrosu zasiadali w sądzie biskupim, administrowali jego majątkami, zarządzali mieniem nieruchomym diecezji. Z kłyroszan wybierano również namiestników władyków ${ }^{58}$. Namiestnik w okresie nieobecności władyki mógł czasowo zarządzać diecezją lub jej częścią. Taka sytuacja wystąpiła w Brześciu. Cerkiew św. Mikołaja w Brześciu była traktowana jako druga świątynia katedralna. Obok cerkwi Zaśnięcia Najświętszej Maryi Panny we Włodzimierzu cerkiew brzeska była uznawana za drugą świątynię biskupią. Nic też dziwnego, że to właśnie do Brześcia posłano „narieczennogo” biskupa Pafnucego. Eparchia na początku XVI wieku obejmowała zachodni i południowy Wołyń (powiaty włodzimierski i krzemieniecki) oraz południowe i środkowe Podlasie (ziemia brzeska, mielnicka, bielska i drohicka), a więc ziemie Wołynia, Polesie z grodami Brześciem, Wołkowyskiem i Kobryniem oraz tereny nad środkowym Bugiem z Mielnikiem, Drohiczynem i Bielskiem ${ }^{59}$.

Po wyborze ihumena Pafnucego na władykę włodzimiersko-brzeskiego wzrosło znaczenie rodu Sieheniów nie tylko w Bielsku. Rodzina Sieheniów otrzymała liczne zapisy. Przypomnę, że Iwan Sieheniewicz i jego brat Wasyl otrzymali 10 lutego 1514 roku od króla Zygmunta Starego potwierdzenie na ziemię w Studziwodach (Iwan) oraz Puchałowszczyznę i Hryniewicze (Wasyl). Po śmierci króla Aleksandra Zygmunt I Stary oddał w 1507 roku Bielsk i starostwo bielskie

58 L. Bieńkowski, Organizacja Kościoła wschodniego w Polsce XVI-XVIII w., [w:] Kościót w Polsce. Studia nad historia Kościoła katolickiego w Polsce, (red.) J. Kłoczowski, t. II, cz. 2, Kraków 1969, s. 806-807; A. Mironowicz, Kościót prawosławny w dziejach dawnej Rzeczypospolitej, Białystok 2001, s. 29-32.

59 A. Mironowicz, Diecezja włodzimierska do końca XVI wieku, „Przegląd Wschodnioeuropejski”, nr 4, Olsztyn 2013, s. 13-23; idem, Przynależność diecezjalna Brześcia do końca XVI wieku, „Białoruskie Zeszyty Historyczne”, 2007, nr 27, s. 5-16. 
w dożywocie księżnej Helenie. Księżna przez swoich pełnomocników zarządzała nim do 1513 roku. Po jej śmierci wójtostwo bielskie objął mieszczanin ruski Iwan Sieheniewicz, kuzyn biskupa Pafnucego. Iwan Sieheniewicz odsprzedał wójtostwo bielskie „,prawem wieczystym” wojewodzie wileńskiemu Mikołajowi Mikołajewiczowi Radziwille (1510-1521) ${ }^{60}$. Po śmierci wojewody wójtostwo przeszło w 1522 roku w ręce podczaszego Jana Radziwiłła (1517-1542), syna Mikołaja, który dbał o własne interesy kosztem ludności miejskiej ${ }^{61}$. Konflikt między wójtem a mieszkańcami przybierał na sile. Jego rozwiązanie mogło nastąpić przez wykup wójtostwa od podczaszego królewskiego Jana Radziwiłła. Na prośbę burmistrza miasta Zygmunt Stary zezwolił 27 grudnia 1526 roku burmistrzowi i Radzie miasta Bielska na wykup wójtowstwa od Radziwiłłów. Monarcha wyraził zgodę, ażeby Iwan Sieheniewicz zapłacił podczaszemu za wójtostwo 300 kop groszy i wezwał, ażeby radni miejscy i burmistrz dokonali wyboru ,godnego wójta" ${ }^{2}$. Nie wiadomo dlaczego Iwan Sieheniewicz nie uiścił deklarowanej kwoty i wójtostwo pozostało w rękach Jana Radziwiłła.

$\mathrm{W}$ tej sytuacji miasto dokonało wykupu wójtostwa dopiero w 1534 roku a wójtem został wybrany jeden z najbogatszych mieszczan Fedko Sieheniewicz. On to pożyczył miastu 450 kop groszy potrzebnych do sfinalizowania transakcji wykupu wójtostwa u Jana Radziwiłła ${ }^{63}$. Fedko Sieheniewicz otrzymał wójtostwo nie tylko z powodu udzielonej miastu pożyczki, ale również z uwagi na wielkie zaufanie, jakie posiadał wśród mieszkańców. Sieheniewicz miał trzymać wójtostwo prawem zastawnym aż suma zostanie mu zwrócona. Dochody z posiadania wójtostwa były na tyle intratne, że zabiegała o te stanowiska magnateria. Osoby piastujące urząd wójta starały się wyciągnąć dla siebie jak najwyższe dochody. Od 1501 roku dziedziczny i nieusuwalny wójt był rzeczywistym reprezentantem miasta ${ }^{64}$.

$$
* * *
$$

W aktach Metryki Litewskiej (Zapisy, księga VIII, k. 503v) znajduje się zapis z 13 sierpnia 1512 roku o przekazaniu przez marszałka i pisarza nadwornego Bogusza Bohowitynowicza (1511-1530) ,narieczennomu” biskupowi Pafnucemu adamaszku na ubranie. „Августа 13, инд. 15, нареченному владыце Володимерскому и Берестейскому Пафнотію даю 20 локотъ одамашки на

\footnotetext{
60 A. Jabłonowski, „Źródła dziejowe”, t. XVII, cz. 2, Podlasie, t. VI, cz. 2, Polska XVI wieku, Warszawa 1910, s. 60.

61 A. Jabłonowski, „Źródła dziejowe”, t. XVII, cz. 2, Podlasie, t. VI, cz. 2, s. 97.

62 „Вестник Западной России. Историко-литературный журнал”, г. VII, кн. 11, т. IV, отд. 1, Вильно 1869, s. 32-34.

63 Ostatecznie Jan Radziwiłł otrzymał kwotę 300 kop groszy. I. T. Baranowski, Podlasie w przededniu Unii Lubelskiej, „Przegląd Historyczny”, t. VII, Warszawa 1908, s. 187-188.

64 A. Jabłonowski, „Źródła dziejowe”, t. XVII, cz. 2, Podlasie, t. VI, cz. 2, s. 72.
} 
мантію сь скарбу"65. Po śmierci władyki Wassiana II w 1512 roku Pafnucy objął po nim katedrę włodzimiersko-brzeską. Chirotonia na biskupa nastąpiła w końcu 1512 roku lub na początku 1513 roku $^{66}$.

Po raz pierwszy, jako samodzielny biskup włodzimiersko-brzeski, Pafnucy występuje w dokumencie z 30 stycznia 1513 roku. W tym to bowiem dniu władyka Pafnucy otrzymał od Zygmunta Starego potwierdzenie na ziemię kwasowską i dobra cerkiewne zwane „Leśne”, jako uposażenie biskupów włodzimierskich posiadanych od czasów Kazimierza Jagiellończyka. Król nadał tę ziemię ówczesnym biskupom włodzimierskich: Nikiforowi ${ }^{67}$ i Damianowi ${ }^{68} \mathrm{z}$ pozwoleniem na założenie miasteczka na prawie magdeburskim i poboru dziesięciny od połowy mieszczan włodzimierskich ${ }^{69}$. Tego samego dnia monarcha wystawił władyce Pafnucemu jeszcze dwa dokumenty. Jeden potwierdzał zapisy poprzednich władców dla katedralnej cerkwi Zaśnięcia Najświętszej Maryi

65 „Lietuvos Metrika” (1499-1514), Knyga nr 8, Vilnius 1995, nr 618, s. 459; Акты, относяшиеся к истории Западной России, собранные и изданные Археографическою комиссиею, Санкт-Петербург, 1848. t. II, 1506-1544 (dalej - АЗP), przypis 92 do dokumentu nr 92. „Мантїљ”, gr. Mandyas - mandia: długie, szerokie okrycie bez rękawów - część wierzchniego uroczystego stroju biskupów, archimandrytów i mnichów. Mandia biskupia jest wykonana z tkaniny jedwabnej koloru hiacyntowego, z długimi z góry spadającymi pasami oraz z aksamitnymi tablicami na piersi. A. Znosko, Słownik cerkiewnostowiańsko-polski, Białystok 1996, s. 162.

${ }^{66}$ Архив Санкт-Петербургского института истории Российской Академии Наук в Санкт-Петербурге, ф. 52, оп. 1, нр. 359, к. 20об.; Н. И. Теодорович, Город Владимир Волынской губернии в связи с историей волынской епархии, исторический очерк, Почаев 1893, s. 48; В. І. Ульяновський, Історія иеркви та релігійної думки в Україні у трьох книгах, кн. 1: Середина XV-кінеи XVI столітmя, Кіїв 1994, s. 93; П. Строевъ, Списки іерарховъ и настоятелей монастырей Россіскія иеркви, Санкт-Петербург 1877, s. 1038; А. Никольскій, Пафнутій, „Русскій Біографическій Словарь”, t. ХІІІ, Санкт-Петербург 1902, s. 407; D. Blażejowskyj, Hierarchy of the Kyivan Church (861-1990), Romae 1990, s. 209. Za 1514 rokiem jako datą objęcia katedry biskupiej opowiadali się inni badacze: Митрополит Макарий, История Русской Церкви, t. IX, Москва 1879, s. 299 i A. Boniecki, Poczet rodów w Wielkim Księstwie Litewskim w XV i XVI wieku, Warszawa 1887, s. III.

67 Nikifor biskup włodzimierski (1458); Архив Юго-Западной России, издаваемый Временною комиссиею для разбора древних актов, высочайше уирежденною при Киевском военном, Подольском и Волынском генерал-губернаторе (dalej - АЮЗР), Акты о иерковно-религиозных отношениях в Юго-Западной Руси. (1322-1648 г2.), ч. 1., т. VI, Киев 1883, s. 18-20; Н. Діевъ, Девятисотльетіе Руссксй Иерахіи, 988-1888, Епархіи и Архіереи, Москва 1888, s. 27; П. Строевъ, Списки іерарховъ и настоятелей монастырей Россіскія иеркви, s. 1038; В. І. Ульяновський, Історія цепкви та релігійної думки в Україні ы трьох книгах, кн. 1, s. 92; D. Blażejowskyj, Hierarchy of the Kyivan Church (861-1990), s. 209.

68 Damian, biskup włodzimierski (1487). АЮЗР, ч. 1, т. VI, s. 18-20; В. I. Ульяновський, Історія церкви та релігійної думки в Украӥні ы трьох книгах, s. 92.

69 „Биль намъ чоломъ владыка Влодимерский и Берестейский Пахнотый и покладалъ передъ нами листь отца нашего Казымера, корола Его милости, што его милость предка его владыку Демяна зъ земенином Волынскимъ зъ Барсапомъ о землю церковную на имя о Квасовскую". АЮЗР, ч. 1, т. VI, нр. 11, s. 19. 
Panny we Włodzimierzu ${ }^{70}$, a drugi przywracał dziesięcinę na cerkiew zamkową św. św. Joachima i Anny, odebraną pod koniec XV wieku przez starostę Iwana Jursza (1488-1489) ${ }^{71}$. Za zgodą króla Zygmunta Starego 1 września 1513 roku biskup Pafnucy przekazał księciu Andrzejowi Aleksandrowiczowi Sanguszce ${ }^{72}$, włodzimierskiemu staroście (1508-1528), część swych dóbr cerkiewnych.

Я, владыка Влодимерский и Берестейский Пахнотий, сознаваю симъ моимъ листомъ, ижъ дозволеніемъ господина нашого, корола Его милости Живгимонта, далъ есми князю Андрею Александровичу, старости Володимерскому, м'сца своего церковного городского у подовжь (въ длину) семи сажен а в поперек десят сажон и къ его милости мъсцу, ато для того, что у его милости мғсца мало было, а моего было много, а мне и церкви Божьей то не шкодно ${ }^{73}$.

Władyka ponadto przekazał ziemię cerkiewną o powierzchni 70 sążni kwadratowych na terenie zamku włodzimierskiego dla dworu księcia Andrzeja Sanguszki. Akt przekazania potwierdził król Zygmunt Stary 4 stycznia 1514 roku $^{74}$. Starosta włodzimierski ks. Andrzej Sanguszko zabrał część ziemi należącej do cerkwi św. Paraskiewy i dołączył ją do cerkwi zamkowej św. św. Joachima i Anny. Fakt ten wywołał protesty duchownego piątnickiego o. Małofieja, który przedstawił przed sądem dokumenty wskazujące, że cerkiew św. Parskiewy otrzymała owe uposażenie od wielkiego księcia litewskiego Świdrygiełły (1430-1432). Dobra cerkiewne tejże cerkwi miały być zwolnione od wszelkich powinności na rzecz miasta i zamku. Wieloletni spór o tę ziemię trwał jeszcze w latach panowania Zygmunta Augusta ${ }^{75}$. Biskup Pafnucy 5 kwietnia 1514 roku wystarał się u króla potwierdzenie na posiadanie cerkiewnej ziemi bartnej, którą uzyskał wspomniany wyżej biskup turowski Damian po sporze o nią z Choncem

70 Н. И. Теодорович, Город Владимир Волынской губернии в связи с историей волынской епархии, s. 109. АЮЗР, ч. 1, т. VI, нр. 11, s. 20.

71 Н. И. Теодорович, Город Владимир Волынской губернии в связи с историей вольнской епархии, s. 142.

72 Andrzej Aleksandrowicz Sanguszko (zm. 1534) - książę, namiestnik krzemieniecki w latach 1498-1522, bracławski i winnicki w 1500 roku, starosta włodzimierski w latach 1508-1528, marszałek ziemi wołyńskiej w 1522 roku. Syn Aleksandra Sanguszko ożenił się z Marią Ostrogską, z którą miał synów: Romana (zm. 1517), Fiodora oraz córki: Zofię, Marię, Zofię (ur. ok. 1500), Fiedorę, Wasylisę (ur. 1500), Helenę (ur. ok. 1500). Po raz drugi ożenił się z Bohdaną Odyncewicz, z którą miał córkę Hannę (zm. 1561).

73 Archiwum Ksiąząt Sanguszków w Sławucie, wyd. B. Gorczaka, t. III, (1432-1534), Lwów 1890, s. 103-104; Н. И. Теодорович, Город Владимир Вольнской губернии в связи с историей волынской епархии, s. 48.

74 Archiwum Ksiąząt Sanguszków w Stawucie, t. III, s. 106-107.

75 Н. И. Теодорович, Город Владимир Волынской губернии в связи с историей волынской епархии, s. 147. 
Swoiczewskim, decyzją byłego starosty włodzimierskiego Olizara Szyłowicza ${ }^{76}$. We wszystkich dokumentach biskup Pafnucy korzystał z swej pieczęci z wizerunkiem ręki podniesionej do błogosławieństwa: trzy palce otwarte, a dwa ostatnie złożone. W otoku znajdował się napis: + ЕПИСКОПћ ВОЛОДИМЕРСКИЙ + ПАХНОТИЙ ${ }^{77}$.

Sytuacja Cerkwi na początku XVI wieku na terenie diecezji włodzimiersko-brzeskiej była trudna. W 1491 roku Tatarzy spalili miasto ze świątyniami i wymordowali wielu jego mieszkańców. Dopiero nadanie przez Zygmunta Starego w 1509 roku Włodzimierzowi prawa magdeburskiego poprawiło sytuację ekonomiczną miasta. Pomogły w tym ustanowione przez monarchę jarmarki i targi ${ }^{78}$. Biskup Pafnucy, korzystając z nowych ekonomicznych możliwości, podjął remonty wielu zniszczonych cerkwi i monasterów. Remontu wymagała najstarsza świątynia Zaśnięcia Najświętszej Maryi Panny z XII wieku (ufundowana przez księcia Mścisława Izasławowicza). Poza tym, na początku XVI wieku na terenie Włodzimierza znajdowały się cerkwie: św. Dymitra (istniejąca w 1289 roku), Wprowadzenia Najświętszej Maryi Panny do świątyni (spalona w 1859 roku), św. Jerzego (wzniesiona w połowie XIV wieku), św. Joachima i Anny (istniejąca w 1291 roku), św. Prokopa męczennika (zrujnowana w 1695 roku), św. Mikołaja (istniejąca w 1235 roku, a spalona 1794 roku), św. Paraskiewy (istniejąca w I połowie XV wieku), św. Jana Chrzcicielna (istniejąca jeszcze w 1584 roku), św. Jana Złotoustego (istniejąca jeszcze w 1584 roku), św. Łukasza (istniejąca jeszcze w 1695 roku), św. Kosmy i Damiana, św. Michała Archanioła (istniejąca w 1268 roku), św. Apostołów (ufundowana przez księcia Włodzimierza Wasilkowicza ok. 1287 roku, a spalona w 1790 roku) i Przemienienia Pańskiego (wzmiankowana w latach 1508-1760). Przy cerkwiach: św. Michała Archanioła , św. Apostołów, św. Onufrego Wielkiego, Przemienienia Pańskiego i św. Eliasza funkcjonowały monastery ${ }^{79}$. W celu utrzymania tychże świątyń władyka Pafnucy zabiegał o pomoc finansową u wielu darczyńców i domagał się zbiórki pieniężnej w należących do eparchii dekanatach ${ }^{80}$. Za władyki Pafnucego wybudo-

\footnotetext{
76 Rejestr spraw unionis et bonorum ejus, znajdujących się na dziesięciny, sq̨dy, winy, rozpusty, pojemszczyzny i smierszczyzny, Архив Санкт-Петербургского института истории Российской Академии Наук в Санкт-Петербурге, кол. 52, оп. 1, ед. хр. 206, л. 22; Archiwum Ksiażat Sanguszków w Sławucie, t. III, s. 110-111.

77 Opis pieczęci na dokumencie z 1 września 1513 r. Por.: Archiwum Książat Sanguszków w Sławucie, t. III, s. 104.

78 Słownik Geograficzny Królestwa Polskiego i innych krajów słowiańskich, t. XIV, Warszawa 1895 , s. $169,171$.

79 M. Mironowicz, Parafie prawosławne we Włodzimierzu Wołyńskim do końca XVI wieku, [w:] Synody Cerkwi prawosławnej..., s. 167-179; SGKP, t. XIV, s. 169-170.

80 Центральний Державний Історичний Архів України у Львові, ф. 201, оп. 46, спр. 759, арк. 1.
} 


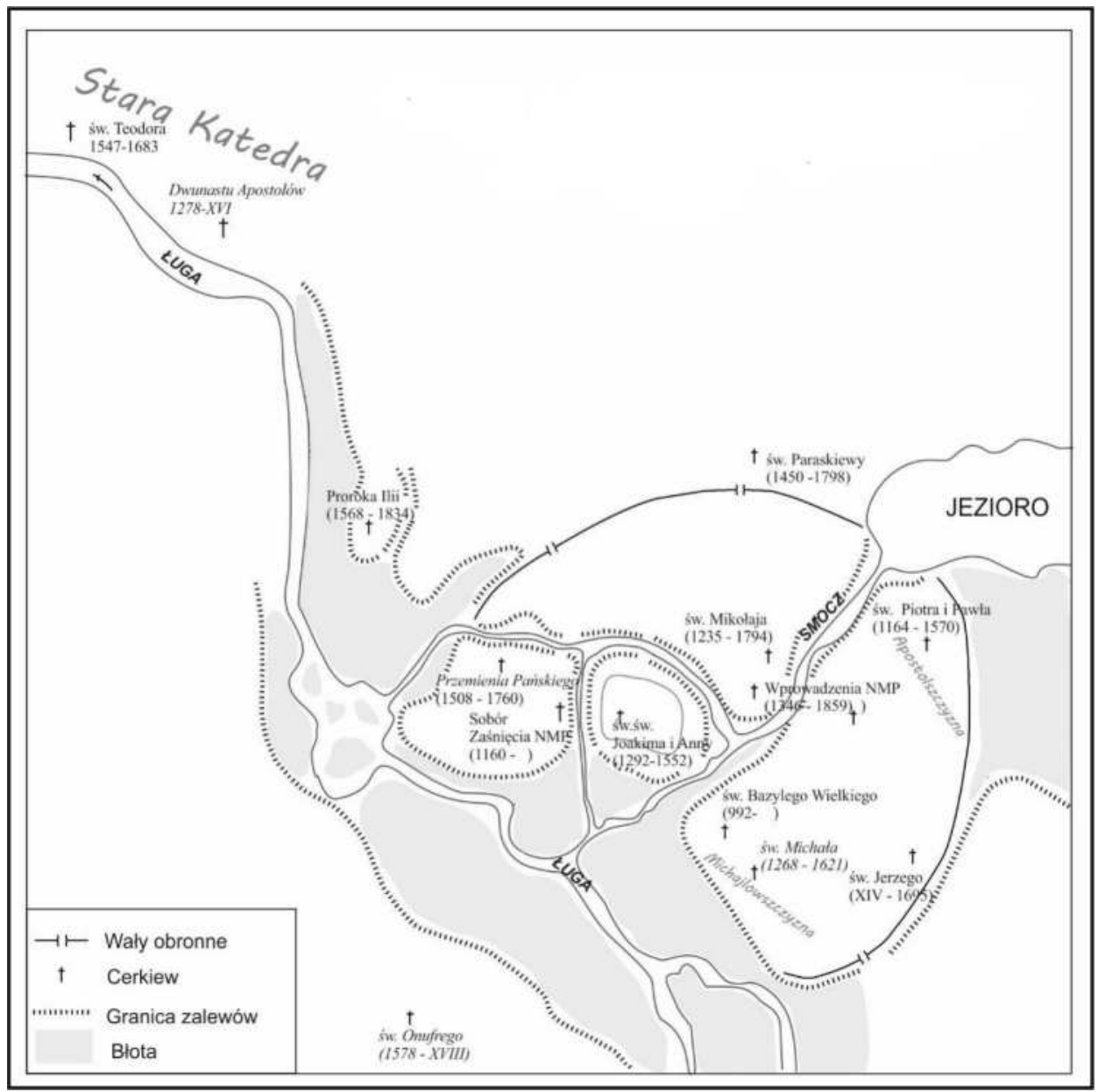

Cerkwie Włodzimierza Wołyńskiego w XVI wieku Źródło: opracowanie własne.

wano też mury obronne z basztami w monasterze Zaśnięcia Najświętszej Maryi Panny we wsi Zimno oraz dwie wieże, z których jedna została wykorzystana jako dzwonnica klasztorna, a druga jako brama wejściowa.

W 1516 roku władyka włodzimierski Pafnucy otrzymał od króla potwierdzenie przywileju wielkiego księcia litewskiego Świdrygiełły nadanego katedralnemu soborowi Zaśnięcia Najświętszej Maryi Panny „na dochody z dań, dziesięcinę, sądy i winy, rozpusty i pojemszczyzny i smierszczyzny z dawna do cerkwi Bożej i władyctwa należące"s1. W tym też roku 4 czerwca nastąpiło rozgraniczenie dóbr należących do diecezji włodzimierskiej, położonych w pobliżu

81 Rejestr spraw unionis et bonorum ejus, znajdujacych się w Metrykach Wielkich Wielkiego 
monasteru w Zimnem od włości księcia Fiodora Michałowicza Czartoryskiego ${ }^{82}$. Dobra rozgraniczono wzdłuż rzek Horeczow i Ług, a dodatkowo władyka pobudował młyn na rzece ku pamięci św. Efrema ${ }^{83}$. Monaster w Zimnem był wówczas rezydencją ordynariuszy eparchii włodzimiersko-brzeskiej.

Dwa lata później Mikołaj Radziwiłł - wojewoda wileński i kanclerz litewski (1510-1521) - w obecności metropolity kijowskiego Józefa Sołtana, władyki włodzimiersko-brzeskiego Pafnucego i ihumena Antoniego ${ }^{84}$ - doprowadził do rozgraniczenia ziem należnych do monasteru supraskiego. Granica dóbr choroskich i suraskich oraz ziem należących do monasteru supraskiego wyznaczała także granicę eparchii metropolitarnej i włodzimiersko-brzeskiej. Wyznaczona w 1518 roku granica między obu diecezjami przetrwała do dziś.

Jan i Elżbieta Łuszczewscy 5 stycznia 1520 roku przekazali na rzecz biskupa włodzimierskiego Pafnucego dobra zastawne Rastów za sumę 150 kop groszy litewskich i 30 złotych, które pierwszy mąż Elżbiety Tworyan Dremlik trzymał w zastawie od Stanisława Bartoszewicza ${ }^{85}$. Ostatecznie, 30 marca 1520 roku władyka Pafnucy zrzekł się dóbr zastawnych Rastów za sumę 150 kop groszy litewskich i 30 złotych na rzecz księcia Andrzeja Aleksandrowicza Sanguszko ${ }^{86}$.

Biskup Pafnucy cieszył się wielkim autorytetem moralnym. $\mathrm{Z}$ tego powodu często uczestniczył w rozstrzyganiu sporów między możnowładztwem prawosławnym. Władyka włodzimierski 21 marca 1521 roku doprowadził do ugody ziemian Jana i Elżbiety Łuszczewskich z ks. Andrzejem Michajłowiczem Sanguszko $^{87}$. Spór dotyczył strat, jakie jedna i druga strona poniosła w wyniku wyrządzonych wzajemnych najazdów ${ }^{88}$. Dokument ten po raz ostatni wymie-

Księstwa Litewskiego, metropolia całej Rusi, Архив Санкт-Петербургского института истории Российской Академии Наук в Санкт-Петербурге, кол. 52, оп. 1, ед. хр. 50, л. 9об, 10об-11; Rejestr spraw unionis et bonorum ejus, znajdujacych się na dziesięciny, sady, winy, rozpusty, pojemszczyzny i smierszczyzny, ibidem, kol. 52, op. 1, ed. hr. 206, 1. 22; „Lietuvos Metrika” (1511-1518), Knyga nr 9, Vilnius 2002, s. 31.

82 Książę Fiodor Michajłowicz Czartoryski, syn księcia Michała Wasilewicza Czartoryskiego i Marii Niemir, starosta łucki (1522-1542).

83 АЮЗР, ч. VII, т. 1, Киев 1886, s. 13-14.

84 AP w Krakowie, AMCh, sygn. 36, nr 29, k. 15; „Вестник Западной России”, г. V, кн. 9, т. III, s. 15-17; H. Surynowicz, Pod opiekq Matki Bożej, s. 27.

85 Archiwum Książą Sanguszków w Sławucie, t. III, s. 195.

86 Ibidem, s. 198; Н. И. Теодорович, Город Владимир Волынской губернии в связи с историей вольнской епархии, s. 49. Po latach, 18 sierpnia 1528 roku Jan Jurewicz Hlebowicz, jako spadkobierca Stanisława Bartoszewicza, dziedzica dóbr Rastowa, zastawia u ks. Andrzeja Sanguszki, marszałka ziemi wołyńskiej, starosty włodzimierskiego, powyższe dobra za sumę 150 kop groszy litewskich i 30 złotych, które książę otrzymał w zastaw od biskupa włodzimierskiego Pafnucego. Archiwum Ksiażąt Sanguszków w Stawucie, t. III, s. 332.

87 Książę Andrzej Michajłowicz Sanguszko (1476-1560), marszałek hospodarski.

88 Archiwum Książą Sanguszków w Stawucie, t. III, s. 206; Н. И. Теодорович, Город Владимир Вольнской губернии в связи с историей волынской епархии, s. 49. 
nia biskupa Pafnucego jako władykę włodzimiersko-brzeskiego. Między marcem a wrześniem 1521 roku za zgodą królewską Pafnucy objął bogatszą diecezję łucko-ostrogską. W dokumencie z 20 września 1521 roku wymienia się we Włodzimierzu już władykę Jonę, byłego ihumena supraskiego ${ }^{89}$. „Я, епископъ Влодимерский и Берестейский Иона, чину явне и вызнавю самъ по себе симъ моимъ листомъ, што предокъ мой, владыка Влодимерский и Берестейский Пахнотий...”. W tym samym źródle wspomina się, że „еп. Пахнотей на инъшую епископъю зъехал"90. W innych źródła podaje się, że biskup Pafnucy był na kwaterze we Włodzimierzu w latach 1512-1526 ${ }^{91}$. Prawdopodobnie władyka Pafnucy był jeszcze we Włodzimierzu w 1522 roku. Świadczy o tym dokument królewski Zygmunta I z 22 września 1522 roku, w którym nakazywał marszałkowi ziemskiemu, staroście drohickiemu i słonimskiemu Januszowi Mikołajowi Radziwille ${ }^{92}$ ściągnąć od duchownych prawosławnych powiatu drohickiego podatek zwany „kunica”, należny biskupowi włodzimierskiemu Pafnucemu ${ }^{93}$. Pisarz królewski Kopieć 12 kwietnia 1522 roku sporządził akt zamiany ziem między księciem Wasylem Michajłowiczem Sanguszko ${ }^{94}$ a władyką włodzimierskim Pafnucym. Należąca do biskupa wieś Tyszkowicze z 23 ludźmi została zamieniona na inne dobra ziemskie ${ }^{95}$. Król Zygmunt I 28 kwietnia 1523 roku nadał księciu Wasylowi Sanguszce prawo patronatu nad cerkwią św. Bazylego Wielkiego, która stopniowo popadała w ruinę i potrzebowała ktitora ${ }^{96}$.

Biskup Pafnucy otrzymał jeszcze za życia swego poprzednika, starego i schorowanego - Cyryla (1498-1526), katedrę łucką. Pafnucy, jako biskup włodzimiersko-brzeski, zwrócił się z prośbą do króla, aby w razie śmierci biskupa Cy-

\footnotetext{
89 Archiwum Ksiażąt Sanguszków w Sławucie, t. III, s. 206; Н. И. Теодорович, Город Владимир Волынской губернии в связи с историей волынской епархии, s. 49.

90 Archiwum Książą Sanguszków w Stawucie, t. III, s. 210-211. W dokumencie tym rok jego wystawienia nie zgadza się z indyktem, według którego powinien być 1520 . Z uwagi jednak na dokument z 3 marca 1521 roku, w którym bp Pafnucy występuje jeszcze jako władyka włodzimierski, należy uznać podany indykt jako mylny, a dokument datować na 1521 rok.

91 Акты относящиеся к истории Западной России, t. II, Санкт-Петербург 1848, нр. 146, s. 178; D. Blażejowskyj, Hierarchy of the Kyivan Church (861-1990), Romae 1990, s. 210; Po 1522 roku biskup Pafnucy został ordynariuszem diecezji łucko-ostrogskiej (1522-1528). Н. Діевъ, Девятисотльетіе Руссксй Иерахіи, 988-1888, Епархіи и Архіереи, Москва 1888, s. 26. Według tego samego źródła objęcie katedry łuckiej nastąpiło we wrześniu 1526 roku. Ibidem, s. 43.

92 Jan Mikołaj Radziwiłł (1474-1522) starosta słonimski, marszałek ziemski litewski, kasztelan trocki.

93 Центральний Державний Історичний Архів України у Львові, ф. 201, оп. 46, спр. 759, арк. 1.

94 Wasyl Michajłowicz Sanguszko (zm. 1558) - książę, dworzanin królewski w 1508 roku, dzierżawca świsłowicki w 1543 roku.

95 Архив Санкт-Петербургского института истории Российской Академии Наук в СанктПетербурге, кол. 52, оп. 1, ед. хр. 50, л. 24.

96 Archiwum książat Lubartów Sanguszków w Sławucie, Lwów 1887, t. 3, s. 251.
} 
ryla, który był „у великой старости и у хворобњ” nadał mu biskupstwo łuckie. O jego nominację zabiegał wojewoda trocki, książę Konstanty Ostrogski i kasztelan trocki, Jerzy Radziwiłł ${ }^{97}$ oraz inni możni prawosławni. „(...) Маетъ епископъ Пафнотей тое владычество Луцкое, по животь епископа Кирила держати"98. Objęcie oficjalne katedry w Łucku przez władykę Pafnucego nastąpiło dopiero po 8 wrześniu 1526 roku, po śmierci biskupa Cyryla ${ }^{99}$. Nie ulega wątpliwości, że biskup Pafnucy w imieniu sędziwego władyki Cyryla zarządzał eparchią łucko-ostrogska od 1523 roku, o czym świadczy przywilej króla Zygmunta Starego naznaczający go na katerę w Łucku, jako biskupa „nareczenego”"100.

Rozbieżność co do czasu objęcia katedry łucko-ostrogskiej jest trudna do wytłumaczenia. Wiadomo, że w 1521 lub 1522 roku do katedry włodzimierskiej przybył biskup turowski Jona, były ihumen supraski. Władyka Jona nie był wikarym biskupa Pafnucego, ponieważ praktyki takiej nie stosowano. Biskup turowsko-piński Jona nie mógł być też namiestnikiem biskupa włodzimierskiego. Obaj hierarchowie doskonale znali się z monasteru supraskiego. Obydwaj znajdowali się w doskonałych relacjach z metropolitą Józefem Sołtanem. Zamiana na katedrach biskupich nastąpiła w roku śmierci metropolity Józefa Sołtana (1522), ale decyzję podjęto jeszcze za jego życia. Co spowodowało przejęcie przez władyków: Pafnucego i Jonę dwóch najbogatszych katedr biskupich na Wołyniu? Analiza sytuacji w katedrach biskupich i korzystanie przez króla z prawa „podawania” $\mathrm{i}$,ktitorstwa” ${ }^{101}$ wskazuje na inną przyczynę. Zmiana w katedrze włodzimierskiej była dokonana pod wpływem starań pisarza królewskiego Michała Ewłaszkowicza Kopcia (1470-1531) o przywilej na biskupstwo łuckie bądź włodzimierskie dla swego ojca Wasyla. Ostatecznie Wasyl Ewłaszkowicz Kopeć otrzymał od Zygmunta Starego 4 sierpnia 1520 roku taki przywilej na „епискупъю, которая се напервеи отворит Луцъкая або Володимерская. (...) Маеть отец его пан Василец тую епискупъю деръжати до живота своего совсимъ по тому, какъ

\footnotetext{
97 Jerzy Radziwiłł, kasztelan trocki (1522-1541), hetman wielki litewski (1531-1541).

98 Акты, относящиеся к истории Западной России, собранные и изданные Археографическою комиссиею, Санкт-Петербург, 1848. т. II, 1506-1544 (dalej - АЗР), нр. 146, s. 178; K. Chodynicki, Kościót prawosławny a Rzeczpospolita Polska. Zarys historyczny 1370-1632, Warszawa 1934, s. 135.

99 Przywilej króla Zygmunta Starego dany Pafnucemu na katedrę łucką, Архив Санкт-Петербургского института истории Российской Академии Наук в Санкт-Петербурге, ф. 52, оп. 1, нр. 359, к. 23; АЮЗР, ч. 1, т. IX, Киев 1893, нр. 11; A. Lapiński, Zygmunt Stary a Kościót prawosławny, Warszawa 1937, s. 44. Według N. Teodorowicza śmierć biskupa Cyryla nastąpiła 18 stycznia 1526 roku. Por.: Н. И. Теодорович, Историко-статистическое описание волынской епархии, т. I, Почаев 1888, s. 19.

100 Архив Санкт-Петербургского института истории Российской Академии Наук в Санкт-Петербурге, ф. 52, оп. 1, нр. 359, к. $250 б$.

101 K. Chodynicki, Kościót prawostawny a Rzeczpospolita Polska, s. 107-120; A. Mironowicz, Kościót prawosławny w państwie Piastów i Jagiellonów, Białystok 2003, s. 213-225.
} 
и иные епископи першие держивали" ${ }^{102}$. Monarcha zdecydował się na takie posunięcie, ponieważ Michał Wasilewicz Ewłaszkowicz Kopeć został wysłany przez Zygmunta Starego do Ordy Perekopskiej, ażeby przekupić Tatarów. W czasie podróży okazało się, że suma sto kop groszy, którą otrzymał od króla jest niewystarczająca i pisarz królewski zmuszony był wyłożyć własne pieniądze. Za tę usługę pisarz królewski żądał od Zygmunta Starego przywileju na katedrę biskupią dla swego ojca. Monarcha wydając taki przywilej niczego nie ryzykował, ponieważ katedry były obsadzone, ale stwarzał niebezpieczny precedens sprzedaży nominacji na stanowiska biskupie i wyznaczanie następców na ordynariuszy diecezji jeszcze za życia funkcjonującego władyki ${ }^{103}$. Praktyka taka była sprzeczna z postanowieniami soboru wileńskiego z 1509 roku, według których nie wolno było starać się o biskupstwo niewakujące. Ponadto, kandydata mieli wybierać książęta i możni wyznania prawosławnego wakującej diecezji, a obrany kandydat musiał mieć zgodę metropolity i biskupów ${ }^{104}$. W przypadku Wasyla Ewłaszkowicza o wyborze zdecydował innowierczy król, bez opinii możnych prawosławnych i zgody metropolity Józefa Sołtana.

Wasyl Ewłaszkowicz był całkowicie nieprzygotowany do pełnienia funkcji biskupiej, a przywilej otrzymał za zasługi jego syna w służbie dla króla. Zachodziła obawa, że jedna z najważniejszych katedr biskupich przejdzie w ręce osoby nieprzygotowanej. Wiadomość o wydaniu przywileju Wasylowi Ewłaszkowiczu spowodowała reakcję elit prawosławnych. Decyzje o obsadzie biskupstw włodzimierskiego i łuckiego zapadły w gronie trzech hierarchów: metropolity Józefa Sołtana, biskupa włodzimiersko-brzeskiego Pafnucego i władyki turowsko-pińskiego Jony. W tych układach musiał uczestniczyć archimandryta leszczyński Makary, były protopop wileński i spowiednik ks. Heleny, który w 1522 roku objął katedrę turowską. Wszyscy doskonale znali się z okresu pobytu w monasterze supraskim i wielokrotnie spotykali się na soborach lokalnych. Duchowni ci cieszyli się zaufaniem króla i posiadali poparcie świeckich elit prawosławnych, w tym książąt: Konstantego Ostrogskiego, Jerzego Radziwiłła, Andrzeja

102 Архив Санкт-Петербургского института истории Российской Академии Наук в Санкт-Петербурге, ф. 52, оп. 1, нр. 359, к. 25; Lietuvos Metrika (1440-1523), Knyga nr 10, Vilnius 1997, nr 75, s. 82; АЮЗР, ч. 1, т. II, Киев 1864, s. 129.

103 АЮЗР, ч. 1, т. И, Киев 1859, нр. 4, 5, 6, s. 7-17; Митрополит Макарий, История Русской Церкви, t. IX, Москва 1879, s. 337-340; K. Chodynicki, Kościót prawosławny a Rzeczpospolita Polska, s. 135.

104 Митрополит Макарий, История Русской Церкви, кн. V, Москва 1996, s. 119, 193; А. Łapiński, Zygmunt Stary a Kościół prawosławny, Warszawa 1937, s. 44; A. Mironowicz, Sobory wileńskie 1509 i 1514 roku, (Synody Cerkwi prawosławnej w I Rzeczypospolitej). „Latopisy Akademii Supraskiej”, t. V, (red.) M. Kuczyńska i U. Pawluczuk, Białystok 2014, s. 71-82. Według A. Jaruszewicza za nadaniem biskupstwa Ewłaszkowiczowi stał książę Konstanty Ostrogski, por.: A. Jaruszkiewicz, Riewnitiel prawosławia kniaź Konstantin Iwanowicz Ostrożskij (1461-1530) i prawostawnaja litowskaja Ruś w jego wriemia, Smoleńsk 1897, s. 195. 
Aleksandrowicza i Wasyla Michajłowicza Sanguszków i Fiodora Michałowicza Czartoryskiego.

Jeszcze za życia metropolity Józefa Sołtana, prawdopodobnie w 1521 roku, dokonano wyboru „nareczenych” biskupów. Źródła tytułują Jonę jako biskupa „nareczenogo" na katedrę włodzimierską, tzn. wybranego przez sobór biskupi, potwierdzonego przez monarchę i oczekującego na samodzielne objęcie katedry. Podobna sytuacja była z władyką Pafnucym, który występuje jako biskup łucki za życia władyki Cyryla. Ostatecznie Pafnucy został ordynariuszem diecezji łuckiej we wrześniu 1526 roku. Pobyt biskupa Pafnucego w katedrze łuckiej okazał się krótki. Władyka Pafnucy zmarł przed 24 kwietniem 1528 roku, ponieważ w tym dniu król nadał przywilej na katedrę biskupią w Łucku władyce turowsko-pińskiemu Makaremu ${ }^{105}$.

\section{Unknown history of the first hegumen of Suprasl}

Pafnucy Siehen, from Bielsk, was the founder of the Suprasl monastery. He was the one who had the biggest contribution to the creation of the first churches, financial security and determination of the status of the monastery in the Orthodox Church. The Siehen family incurred costs of raising the monastic congregation in Gródek. The Siehens, who co-founded the construction of the monastery, received numerous estates from King Sigismund the Old (Zygmunt Stary). Pafnucy Siehen created a well-organized religious community and supervised legal and material protection of his monastery. At the beginning of 1509 Hegumen Pafnucy Siehen made a request to the king for permission to build a stone Orthodox church of the Annunciation of the Blessed Virgin Mary. The construction of the church began in October 1510. According to the majority of historians, this year was the date of Pafnucy Siehen's death. On the basis of new evidence, it has been proven that Pafnucy Siehen did not die that year; he participated in the council of Vilnius in 1509-1510. At this council Pafnucy Siehen, the hegumen of Supraśl, was declared a bishop.

After bishop Wassian's death in 1512, Pafnucy Siehen became the ordinary of Vladimir-Brest diocese. His nomination was supported by the Metropolitan of Kiev, Joseph and secular Orthodox elites. After choosing hegumen Pafnucy the Vladimir-Brest leader, the importance of the Siehen family rapidly increased. Bishop Siehen, as a bishop, initiated the restoration of numerous churches and monasteries destroyed during the Tatar invasion in 1491. In the years 1514-1516 Pafnucy received from the king the confirmation of privileges granted to the episcopate and the Cathedral of the Dormition in Vladimir-Volynski. Bishop

105 Архив Санкт-Петербургского института истории Российской Академии Наук в Санкт-Петербурге, ф. 52, оп. 1, нр. 359, к. 23; АЗР, т. ИИ, нр. 151, s. 187. 
Pafnucy managed the Lutsk-Ostroh diocese since 1523 . He officially took over the Lutsk diocese after the death of bishop Cyril in 1526. Pafnucy Siehen held his episcopal function in Lutsk until 1528.

Key words: Orthodox Church, hegumen of Suprasl, Vladimir-Brest diocese

\section{Bibliografia}

\section{Źródła rękopiśmienne}

Archiwum Diecezjalne Kościoła Rzymskokatolickiego w Białymstoku, nr 245.

Archiwum Państwowe na Wawelu, Archiwum Młynowskie Chodkiewiczów, sygn. 35; 36, nr 29.

Archiwum Państwowe w Lublinie, Zespół Chełmski Konsystorz Greckokatolicki, sygn. 101.

Biblioteka Litewskiej Akademii Nauk im. Wróblewskich w Wilnie, sygn. f. 19, nr 89; f. 16, B 2, nr 134 .

Biblioteka Muzeum Narodowego im. Czartoryskich w Krakowie. Zbiór dokumentów pergaminowych, nr 53 (MNK 540/13); nr 66 (MNK 541/1); nr 76 (MNK 541/8); nr 860 , t. I.

Biblioteka Narodowa w Warszawie, Biblioteka Ordynacji Zamojskich, Dział Rękopisów, nr 930.

Biblioteka Uniwersytetu Wileńskiego w Wilnie. Oddział Rękopisów, F58-7, B 1993, B 1994, B 2001, B 2002.

Lietuvos valstybės istorijos archyvas, Vilnius, f. 634, op. 1, nr 3, 50, 58.

Архив Санкт-Петербургского института истории Российской Академии Наук в Санкт-Петербурге, ф. 52, оп. 1, № 50, 206, 359.

Российская государственная библиотека в Москве, Собрание Е. Е. Егорова, ф. 98, № 39.

Российский государственный исторический архив в Санкт-Петербурге, ф. 823, оп. 3 , № 3317.

Центральний державний історичний архів України у Львові, ф. 201, оп. 46, спр. 759, арк. 1.

\section{Źródła drukowane}

Archiwum Książat Sanguszków w Sławucie, wyd. B. Gorczaka, t. III, (1432-1534), Lwów 1890.

Jabłonowski A., Źródła dziejowe, t. XVII, cz. 2: Podlasie, t. VI, cz. 2: Polska XVI wieku, Warszawa 1910.

„Lietuvos Metrika” (1499-1514), Knyga nr 8, Vilnius 1995. 
„Lietuvos Metrika” (1511-1518), Knyga nr 9, Vilnius 2002.

„Lietuvos Metrika” (1387-1546), Knyga nr 25, Vilnius 1998.

„Lietuvos Metrika” (1440-1523), Knyga nr 10, Vilnius 1997.

Prawa i przywileje miasta i dóbr ziemskich Zabłudów XV-XVIII, opr. J. Maroszek, Białystok 1994.

Rękopisy cerkiewnostowiańskie w Polsce. Katalog, oprac. A. Naumow i in., wyd. 2, Kraków 2004.

Rękopisy supraskie w zbiorach krajowych i obcych, red. A. Mironowicz, Białystok 2014.

Акты, издаваемые Виленскою коммисиею, высочайше учрежденною для разбора древних актов в Вильне, т. I, Вильна 1865; т. III, Вильна 1870; т. VI, Вильна 1872; т. VII, Вильна 1874.

Акты исторические, собранные и изданные Археографической комиссиею, т. I, Санкт-Петербург 1841.

Акты, относящиеся к истории Западной России, собранные и изданные Археографическою комиссиею, т. II, 1506-1544, Санкт-Петербург 1848.

Акты, относящиеся к истории Южной и Западной России, собранные и изданные Археографической комиссиею, т. I, Санкт-Петербург 1863.

Археографический сборник документов, относящихся к истории Северо-Западной Руси, издаваемый при управлении Виленского учебного округа, т. IX, Вильна 1870.

Архив Юго-Западной России, издаваемый Временною комиссиею для разбора древних актов, высочайше учрежденною при Киевском военном, Подольском и Волынском генерал-губернаторе. Акты о иерковно-религиозных отношениях в Юго-Руси (1322-1648 г2.), ч. 1, т. І, Киев 1859; ч. 1, т. II, Киев 1864; ч. 1, т. VI, Киев 1883; ч. 1, т. VII, Киев 1887; ч. 1, т. IX, Киев 1893; ч. 7, т. І, Киев 1886 .

Документы относящиеся к истории Супрасльского монастыря, „Вестник Западной России”, Вильна 1861, г. V, кн. 7, т. II, отд. 2; Вильна 1867, г. V, кн. 8, т. III, отд. 1; Вильна 1869, г. VII, кн. 11, т. IV, отд. 1.

Древнерусские иноческие уставы, подг. текста Т. В. Суздальцева, Москва 2001 (Русский типик).

Е. Н. [Епископ Никонор], Старый Синодик Супрасльского монастыря, „Гродненские Епархиальные Ведомости”, г. IV, 1904, № 27.

Миловидов А. Н., Описание славяно-русских старопечатных книг Виленской публичной библиотеки (1491-1800), составил А. Н. Миловидов, [в:] Отиет Виленской публичной библиотеки и Музея за 1907 год, Вильна 1908.

Полное собрание русских летописей, т. 17, Санкт-Петербург 1907.

Полное собрание русских летописей, т. 35: Летописи белорусско-литовские, Москва 1980.

Прадмова да Памянніка иі Сінодыка з Супрасльскага манастыра 1631 2. (апр. Л. В. Ляўшун), [у:] Рэлігійнае пісьменства кірылічнай традыиыі XI-XV cmсm., Мінск 2013. 
Ревизия пуш и приходов звериных в бывшем Великом княжестве Литовском с присовокуплением грамот и привилегий на входы в пущи и земли, составленная Стростою Мстибоговским Григорием Богдановичем Воловичем в 1559 году, с прибавлением другой актовой книги, содержащей в себе привилегии, данные дворянам и священникам Пинского повета, составленой в 1554 году, Вильна 1867, № 237.

Хроника Русская. Летописеи великих князей литовских, изд. С. Руссов, СанктПетербург 1832.

\section{Literatura}

Abijski M., Bogdan Onisimowicz - śpiewak rodem z Pińska, „Latopisy Akademii Supraskiej”, t. I, (red.) U. Pawluczuk, Białystok 2010.

Aitzetmüller R., Eine russisch-kirchenslavische Parallelhandschrift zum aksl. Codex Suprasliensis. Materialen zu dessen Textgestalt (Suprasliensis - Materialien I-III), „Anzeiger für Slavische Philologie” 1967, no. 2; 1969, no. 3; 1970, no. 4.

Altbauer M., Taube M., The Five biblical scrolls in a sixteenth-century Jewish translation into Belorussian (Vilnius Codex 262), Jeruzalem 1992.

Amse-de Jong T. H., The Meaning of the Finite Verb Forms in the Old Church Slavonic Codex Suprasliensis, Hague - Paris 1974.

Baranowski I. T., Podlasie w przededniu Unii Lubelskiej, „Przegląd Historyczny” 1908, t. VII.

Bieńkowski L., Organizacja Kościoła wschodniego w Polsce XVI-XVIII w., [w:] Kościót w Polsce. Studia nad historia Kościoła katolickiego w Polsce, (red.) J. Kłoczowski, t. II, cz. 2, Kraków 1969.

Bláhová E., Nejstarší staroslověnské homilie. Syntax a lexikon, Praha 1973.

Blażejowskyj D., Hierarchy of the Kyivan Church (861-1990), Romae 1990.

Boniecki A., Herbarz polski, t. III, Warszawa 1900.

Boniecki A., Poczet rodów w Wielkim Księstwie Litewskim w XV i XVI wieku, Warszawa 1887.

Brensztejn M., Zbiory rękopisów Uniwersyteckiej Biblioteki Publicznej w Wilnie, „Atheneum Wileńskie", Wilno 1933, R. VIII.

Chodynicki K., Kościót prawosławny a Rzeczpospolita Polska. Zarys historyczny 1370-1632, Warszawa 1934.

Chrościcka A., Klasztor supraski i jego Retkov Sbornik, [w:] Klasztorne ośrodki piśmiennictwa i kultury w krajach słowiańskich. Biblioteka Ekumenii i Dialogu, t. XXVI, (red.) J. Georgiewa-Okoń i J. Stradomski, Kraków 2005.

Codex Suprasliensis [Project: Codex Suprasliensis Inscribed on the International Register in 2007 Memory of the World] http://csup.ilit.bas.bg/ [dostęp 2.08.2013].

Daniłowicz I., Latopisiec Litwy i kronika ruska z rękopisu słowiańskiego przepisane, Wilno 1927. 
Garzaniti M., Die altslavische Version der Evangelien. Forschungsgeschichte und zeitgenossische Forschung (Bausteine zur slavischen Philologie und Kulturgeschichte. Neue Folge. Reihe A: Slavistische Forschungen. Bd. 33). Böhlau Verlag, Köln Weimar - Wien 2001.

Gębarowicz M., Iwan Fedorow i jego działalność w latach 1569-1583 na tle epoki, „Roczniki Biblioteczne” 1969, R. XIII, z. 3-4 (cz. II).

Gil A., Unickie cerkwie Brześcia w opisie wizytacyjnym z 1726 roku, „Rocznik Instytutu Europy Środkowo-Wschodniej” 2006, nr 4.

Grala H., Kotpak Witołdowy czy czapka Monomacha? (Dylematy wyznawców prawosławia $w$ monarchii ostatnich Jagiellonów), [w:] Katolicyzm w Rosji i prawosławie w Polsce (XI-XX w.), Warszawa 1997.

Jasnowski J., Chodkiewicz Aleksander, Polski Słownik Biograficzny, t. III, Kraków 1937.

Kamiński J., Rodzina Chodkiewiczów herbu Gryf, „Skarbiec Polski”, 1859.

Kaszlej A., Dzieje Kodeksu supraskiego, Supraśl 1997.

Kierejczuk E., Kodeks supraski wśród zbiorów biblioteki monasteru supraskiego. Kilka hipotez w sprawie czasu przybycia Minieji Czetnej z XI wieku do Supraśla, „Latopisy Akademii Supraskiej”, t. II, (red.) U. Pawluczuk, Białystok 2011.

Kossakowski S. K., Monografie historyczno-genealogiczne niektórych rodzin polskich, t. I, Warszawa 1876.

Krustev G., Boyadjiev A., On the Dating of Codex Suprasliensis, [w:] Преоткриване: Супраслъски сборник - старобългарски паметник от Х век, red. A. Miltenova, София 2012.

Laucevičius E., XV-XVIII a. knygu ịišimai Lietuvos bibliotekose, Vilnius 1976.

Lemeškin I., Sovijaus sakme ir 1262 metu chronografas pagal Archyvini, Varšuvos, Vilniaus ir I. J. Zabelino nuorašus, Vilnius 2009.

Luba-Radzimiński Z., Sprawa odrębnego pochodzenia Chodkiewiczów litewskich i białoruskich, „Rocznik Polskiego Towarzystwa Heraldycznego” 1928, R. 1926-1927, t. VIII.

Łapiński A., Zygmunt Stary a Kościół prawosławny, Warszawa 1937.

Łozowska M., Fundacja klasztoru supraskiego w pierwszej połowie XVI wieku. Próba interpretacji dokumentów uposażeniowych, [w:] Małe miasta. Historia $i$ wspótczesność, t. I, Supraśl 2001.

Margulies A., Der altkirchenslavische Codex Suprasliensis, Heidelberg 1927.

Maroszek J., Monografia miasta i gminy Supraśl, Supraśl 2013.

Maroszek J., Pogranicze Litwy i Korony w planach króla Zygmunta Augusta: z historii dziejów realizacji myśli monarszej między Niemnem a Narwią, Białystok 2000.

Maroszek J., Rewelacyjne odkrycie nieznanych najstarszych dokumentów dla Białegostoku, „Białostocczyzna” 1999, nr 1 (53).

Meyer K., Altkirchenslavisch-griechisches Wörterbuch des Codex Suprasliensis, Glückstadt und Hamburg 1935. 
Miklosich F., Monumenta linguae palaeoslovenicae e Codice Supraslienis, Vindobonae 1851.

Mironowicz A., Biblioteka monasteru supraskiego w XVI wieku, „Białoruskie Zeszyty Historyczne" 2011, nr 36.

Mironowicz A., Cerkwie brzeskie w XVI wieku, „Cerkiewny Wiestnik”, 2013, R. LX, nr 4.

Mironowicz A., Diecezja włodzimierska do końca XVI wieku, „Przegląd Wschodnioeuropejski” 2013, nr 4.

Mironowicz A., Ewangelizacja „prosta mowa” w XVI wieku, „Latopisy Akademii Supraskiej”, Białystok 2012, t. III, (red.) U. Pawluczuk.

Mironowicz A., Kodeks supraski, „Białostocczyzna” 1988, nr 1 (9).

Mironowicz A., Kościót prawosławny w dziejach dawnej Rzeczypospolitej, Białystok 2001.

Mironowicz A., Kościót prawosławny w państwie Piastów i Jagiellonów, Białystok 2003.

Mironowicz A., Latopisy supraskie jako jedno ze źródet „Kroniki polskiej...” Macieja Stryjkowskiego, [w:] Studia polsko-litewsko-białoruskie, Prace Białostockiego Towarzystwa Naukowego, nr 31, (red.) J. Tomaszewski, E. Smułkowa i H. Majecki, Warszawa 1988.

Mironowicz A., Najstarszy Субботник или Поминник monasteru supraskiego, „Białoruskie Zeszyty Historyczne" 2013, nr 40.

Mironowicz A., Największa fundacja Aleksandra Chodkiewicza. Spór o charakter fundacji, [w:] Władza i prestiz. Magnateria Rzeczypospolitej w XVI-XVIII wieku, (red.) J. Urwanowicz, Białystok 2003.

Mironowicz A., O początkach monasteru supraskiego i jego fundatorach, Supraśl 2013.

Mironowicz M., Parafie prawosławne we Włodzimierzu Wołyńskim do końca XVI wieku, [w:] Synody Cerkwi prawosławnej w I Rzeczypospolitej, (red.) M. Kuczyńska i U. Pawluczuk, „Latopisy Akademii Supraskiej”, Białystok 2014, t. 5.

Mironowicz A., Podlaskie ośrodki i organizacje prawosławne w XVI i XVII w., Białystok 1991.

Mironowicz A., Przynależność diecezjalna Brześcia do końca XVI wieku, „Białoruskie Zeszyty Historyczne" 2007, nr 27.

Mironowicz A., Sobory wileńskie 1509 i 1514 roku, [w:] Synody Cerkwi prawosławnej w I Rzeczypospolitej, (red.) M. Kuczyńska i U. Pawluczuk, „Latopisy Akademii Supraskiej”, t. 5, Białystok 2014.

Mironowicz A., Summariusz dokumentów do dóbr supraskich, Białystok 2009.

Mironowicz A., Sumariusz dokumentów dóbr supraskich, t. II, Białystok 2011.

Mironowicz A., Supraśl jako ośrodek kulturalno-religijny w XVI wieku, Leimen 1984.

Mironowicz A., Zwiazki literackie Kijowa z monasterem supraskim w XVI wieku, „Slavia Orientalis", 1989, t. XXXVIII, nr 3-4.

Mironowicz A., Zwiazki monasteru supraskiego ze Święta Góra Athos w XVI wieku, [w:] Święta Góra Athos w kulturze Europy. Europa w kulturze Athosu, (red.) M. Kuczyńska, Gniezno 2009. 
Mironowicz A., Życie monastyczne na Podlasiu, Białystok 1998.

Mironowicz A. i M., Św. Antoni Supraski, Białystok 2014.

Naumow A., Monaster supraski jako jeden z głównych ośrodków kulturalnych w Rzeczypospolitej, [w:] Z dziejów monasteru supraskiego, Białystok 2005.

Niesiecki K., Herbarz polski, t. III, Lipsk 1839.

Nikołajew M., Dziesiatagław. 500 lat księgi z Supraśla, „Przegląd Prawosławny” 2007, nr 2.

Papée F., Aleksander Jagiellończyk, Kraków 1949.

Petrowycz W., Prawosławne i greckokatolickie cerkwie Włodzimierza Wotyńskiego, [w:] Do piękna nadprzyrodzonego: Sesja naukowa na temat rozwoju sztuki sakralnej od X do XX wieku na terenie dawnych diecezji chełmskich Kościoła rzymskokatolickiego, prawosławnego, greckokatolickiego, t. I, Chełm 2003.

Polski Słownik Biograficzny, Kraków 1937, t. III; Warszawa - Kraków 1976, t. XXI; Wrocław - Warszawa - Kraków 1993, t. XXXIV; Wrocław - Warszawa - Kraków 1994, t. XXXV.

Rogow A., Supraśl jako jeden z ośrodków więzów kulturalnych Białorusi z innymi krajami stowiańskimi, „Wiadomości Polskiego Autokefalicznego Kościoła Prawosławnego" 1981, nr 3.

Słownik geograficzny Królestwa Polskiego i innych krajów słowiańskich, t. V, Warszawa 1884; t. XIV, Warszawa 1895.

Soszyński R., O dawnym Brześciu i cerkwi Św. Mikołaja kilka uwag, „Podlaski Kwartalnik Kulturalny” 1996, nr 4 (26).

Straty bibliotek $i$ archiwów warszawskich $w$ zakresie rękopiśmiennych źródeł historycznych, t. III, „Biblioteki”, Warszawa 1955.

Szaranowicz I., O latopisach i kronikach ruskich XV i XVI w., „Rozprawy i sprawozdania z posiedzeń Wydziału Historyczno-Filozoficznego Akademii Umiejętności”, Kraków 1882, t. XV.

Szwejkowska H., Ksiązka drukowana XV-XVIII wieku. Zarys historyczny, wyd. 3, Wrocław 1980.

Takala-Roszczenko M., The 'Latin' within the 'Greek': The Feast of the Holy Eucharist in the Context of Ruthenian Eastern Rite Liturgical Evolution in the 16th-18th Centuries, Joensuu 2013.

Uruski S., Rodzina, t. II, Warszawa 1905.

Wereda D., Działalność kapituły $i$ konsystorza przy unickiej katedrze $w$ Brześciu w XVIII w., „Nasza Przeszłość” 2004, t. CII.

Wolff J., Kniaziowie litewsko-ruscy od końca czternastego wieku, Warszawa 1895.

Zivier E., Studien über den Codex Suprasliensis, t. I, Breslau 1892.

Żychliński T., Złota księga szlachty polskiej, R. XI, Poznań 1889.

Алексеев А. А., Лихачева О. П., Супрасльский сборник 1507 г., [в:] Материаль и сообщения по фондам отдела рукописной и редкой книги библиотеки БАН СССР, Ленинград 1978. 
Анисимова Т. В., О некоторых рукописях Супрасльского Благовещенского монастыря в книжных собраниях Москвы, Новгорода и Санкт-Петербурга, „Віbliotheca Archivi Lithuanici”, vol 7, Lietuvos Didžiosias Kunigaikštystès Kalbos, Kultūros ir raštijos tradicijos, (red.) S. Temčinas, Vilnius 2009.

Анисимова Т. В., Супрасльский список Хроники Георгия Амартола, [в:] Лигвистическое источниковедение и история русского языка (2002-2003), Москва 2003.

Белецкий А., Митрополитъ Іосифъ II Солтанъ и отношение его къ Супрасльскому монастырю, Вильна 1899.

Бельчиков Н. Ф., Бегунов Ю. К., Рождественский Н. П., Справочник-указатель печатных описаний славяно-русских рукописей, Москва 1963.

Бобровский П. О., К биографии М. К. Бобровского, Санкт-Петербург 1890.

Бобровский П. О., Судьба Супрасльской рукописи, „Журнал Министерства народного просвещения" 1887, т. 253, т. 254.

Богдановиђ Д., Каталог кирилских рукописа манастира Хиландара, Београд 1978.

Брест. Ениыклопедический справочник, Минск 1987.

Бубнов Н. Д., „Славянские Прологи”. Методическое пособие по описанию славяно-русских рукописей для Сводного каталога рукописей, хранящихся в СССР, выпуск I, Москва 1973.

Бычков А. Ф., Известия о Супрасльской рукописи ХI века, „Известия Императорской академии наук по отделению русского языка и словесности", СанктПетербург 1856, т. V.

Бычков И. А., Каталог собрания рукописей Ф. И. Буслаева ныне принадлежашых Императорской Публичной библиотеке, Санкт-Петербург 1897.

Викторов А. Е., Описи рукописных собраний в книгохранилищах Северной России, Санкт-Петербург 1890.

Востоков А. Л., Супрасльская рукопись. Библиографические листы, Санкт-Петербург 1865.

Галенчанка Г. Я., Невядомыя $і$ малавядомыя помнікі духоўнай спадчыны $і$ культурных сувязей Беларусі XV - сярэдзіны XVII cm., Минск 2008.

Гильтебрандт П. А., Рукописное отделение Виленской публичной библиотеки, вып. 1, Вильна 1871.

Гордиенко Ә. А., Семячко С. А., Шибаев М. А., Миниатюра и текст, СанктПетербург 2011.

Гранстрем Е. Ә., Описание русских и славянских пергаменных рукописей, Ленинград 1953.

Грушевський М., Історія України-Руси, т. V, Київ 1994.

Грушевський М., Історія України-Руси, т. VI, Київ - Львів 1907.

Густова Л., Византийский богослужебно-певческий устав в Супрасльском Благовешенском монастыре (XVI в.), „Latopisy Akademii Supraskiej”, Białystok 2011, t. II, (red.) U. Pawluczuk. 
Данилович И., О литовских летописях, „Журнал Министерства народного просвещения”, 1840, № 11 .

Добрянский Ф., Описание рукописей Виленской публичной библиотеки, церковнославянских и русских, Вильна 1882.

Документы относящиеся к истории Супрасльского монастыря, „Вестник Западной России”, Вильно 1867, кн. 8, т. III, отд. 1.

Дурново Н., Девятисотлетіе Русской Иерархіи. 988-1888. Епархіи и Архіереи, Москва 1888.

Дурново Н., К вопросу о древнейших переводах на старославянский язык библейских текстов: Супрасльская рукопись, „Известия Отделения русского языка и словесности Российской Академии наук”, Санкт-Петербург 1925, т. ХХX.

Запартыка Г., Страчаныя скарбы манастырскіх бібліятэк, [в:] 480 год беларуска-

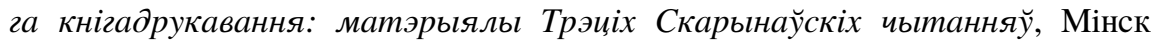
1998.

Иванова-Мавродинова В., Мавродинова Л. Н., Украсата на старобългарските ръкописиси до края на ХІ век, „Кирило-Методиевски студии”, 1999, кн. XIII.

Квитницкая Е. Д., Монастыри Бреста XVII-XVIII вв., „Архитектурное наследство”, Москва 1979, № 27.

Квитницкая Е. Д., Монастыри Бреста XVII-XVIII вв., [в:] Страчаная спадиьлна, уклад. Т. В. Габрусь, Мінск 2003.

Кенанов Д., За текстологията на Симеоновата антология «Златоструй», „Кrakowsko-Wileńskie Studia Slawistyczne”, Kraków 2011, t. VI.

Князевская О. А., Лифшиц А. Л., Турилов А. А., Пергаменные рукописи собрания Виленской публичной библиотеки (Библиотека Академии наук Литовской Республики, фб. 19), „Krakowsko-Wileńskie Studia Slawistyczne”, Kraków 2001, t. III.

Конотоп А., Древнейший памятник украинского нотолинейного письма - Супрасльский ирмологион 1598-1601 г2., „Памятники культуры. Новые открытия (1974)", Москва 1975.

Конотоп А., Супрасльский ирмологий 1638-1639 г2., „Памятники культуры. Новые открытия (1980)", Ленинград 1981.

Кукушкина М. В., Монастырские библиотеки Русского Севера. Очерки по истории книжной культуры XVI-XVII веков, Ленинград 1977.

Лабынцев Ю. А., Об одном важном спросном моменте в судъбах белорусской православной культуры XVI столетия в связи с историей Супрасльского Благовещенского монастыря, „ELPIS. Czasopismo Katedry Teologii Prawosławnej Uniwersytetu w Białymstoku” 2000, R. II (XIII), z. 2 (15).

Лабынцев Ю. А., Православная Академия Ходкевичей и ее издания, Минск 1996.

Лавров П. А., Библейские книги 1507 года, „Slavia - časopis pro slovanskou filologii”, Praha 1933, R. XII, sešit 1-2.

Лавровская И. Б., Судба помятников истории и архитектуры Бреста (XIVXVIII вв.), „Архитектура и строительство Белорусии”, 1991, № 4. 
Лаўроўская I. Б., Старажытная иарква Сьвятога Мікалая ў Берасиі - помнік гісторыі і архітэктуры,, „Наш радавод”, Гродна 1996, кн. 7.

Леонид (Кавелин) арх., Систематическое описание в 4 иастях, с 13 снимками славяно-русских рукописей собрания графа А. С. Уварова, ч. II, Москва 1893.

Лихачев Д. С., Русские летописи и их культурно-историческое значение, Москва - Лениград 1947.

Лихачев Н. П., Палеографическое значение бумажных водяных знаков, ч. I-IV, Санкт-Петербург 1899.

Мірановіч А., Брэсикія иэрквы $\breve{y}$ XVI стагоддзі, [в:] Берасиейскія кнігазборы. Брэсикая Біблія - унікальны помнік культуры XVI стагоддзя: да 450-годдзя выдання: матэрыялы і даклады міжнароднага круглага стала, Брэст, 29-31 мая 2013 г., пад агул. рэд. М. В. Нікалаева, Брэст 2014.

Миронович А., Библиотека Супрасльского монастыря в XVI веке, [в:] Преоткриване: Супраслъски сборник - старобългарски паметник от $X$ век, ред. А. Милтенова, София 2012.

Митрополит Макарий (Булгаков), История Русской Церкви, кн. V, Москва 1996.

Митрополит Макарий, История Русской Церкви, т. IX, Санкт-Петербург 1879.

Модест (Стрельбицкий), Супрасльский Благовещенский монастырь, „Вестник Западной России", Вильна 1865/1866, г. IV, кн. 7, т. III, отд. 2; 1866, г. IV, кн. 7 , т. III, отд. 1; 1867, г. V, кн. 1, т. I, отд. 2; 1867, г. V, кн. 6, т. II, отд. 2; 1867, г. V, кн. 7, т. I, отд. 2; 1867, г. V, кн. 7, т. II, отд. 2.

Молдован А. Ю., Житие Андрея юродивого в славянской письменности, Москва 2000.

Монашество и монастыри в России XI-XX вв: исторические очерки, отв. ред. Н. В. Синицына, Москва 2002.

Морозова Н. А., К вопросу о датировке “Поуиений огласительных” Феодора Cmyдuma, „Kalbotyra”, Vilnius 1997, t. XLV, nr 2.

Морозова Н. А., Кириллические рукописнье книги хранящиеся в Вильнюсе, Vilnius 2008.

Морозова Н. А., Темчин С. Ю., Древнейщие рукописи Супрасльского Благовещенского монастыря (1500-1532 г2.), [w:] Z dziejów monasteru supraskiego, Supraśl - Białystok 2005.

Мошин Вл., Кирилски рукописи повијесног музеја хрватске и Копитарове збирке, Београд 1971.

Немировский Е. Л., Франииск Скорина: жизнь и деятельность белорусского просветителя, Минск 1990.

Нікалаеў М., Гісторыя беларускай кнігі, т. 1, Мінск 2009.

Нікалаеў М., Палата кнігапісная. Рукапісная кніга на Беларусі $\breve{y}$ X-XVIII cmст., Мінск 1993.

Николай (Далматов), Супрасльский Благовещенский монастьрь, Санкт-Петербург 1892. 
Николова С., Патеричните раскази в българската средневековна литература, София 1980.

Никольскій А., Пафнутій, „Русскій Біографическій Словарь”, т. ХІІІ, Санкт-Петербург 1902.

Обнорский С. П., К литературной истории «Хождения» Арсения Солунского, „Известия отделения русского языка и словесности Академии наук”, Москва 1914, т. XIX, кн. 3.

Оболенский А., Супрасльская рукопись, содержащая Новгородскую и Киевскую сокращенные летописи, Москва 1836.

Описание Рукописного отделения Библиотеки Императорской Академии наук, т. I, сост. В. И. Срезневский, Ф. И. Покровский, Санкт-Петербург 1910.

Описание славяно-русских старопечатных книг Виленской публичной библиотеки (1491-1800), составиль А. Н. Миловидов, [в:] Отчет Виленской публичной библиотеки и Музея за 1907 год, Вильна 1908.

Паплонский И., Известие о Супрасльской рукописи, „Варшавские университетские известия" за 1872 г., Неофициальный отдел, Варшава 1873, № 4.

Пергаменные рукописи библиотеки Академии наук СССР. Описание русских и славянских рукописей XI-XVI веков, сост. Н. Ю. Бубнов, О. П Лихачева, В. Ф Покровская, Ленинград 1976.

Петров Н. И., Супрасльский монастьрь как зашитник православия в XVI и в наиале XVII века, „Виленский календарь на 1896 год”, Вильно 1895.

Покровский Ф., Археологическая карта Гродненской губернии, Вильна 1895.

Преоткриване: Супрасълски сборник, старобългарски паметник от X век, ред. А. Милтенова, София 2012.

Проучвания върху Супрасълския сборник, старобългарски паметник от X век, [в:] Доклади и разисквания пред Първия международен симпозиум за Супрасълския сборник, 28-30.IХ.1977, Шумен, ред. Й. Заимов, София 1978.

Рогов А. И., Кириллические рукописи в книгохранилищах Польши, „Studia Źródłoznawcze", Warszawa - Poznań 1969, t. XIV.

Рогов А. И., Литературные связи Белоруссии с балканскими странами в XVXVI вв., [в:] Славянские литературы. VIII Международный съезд славистов, Загреб - Любляна, сентябрь 1978 г. Доклады советской делегации, Moskva 1978.

Рогов А. И., Супрасль как один из иентров культурных связей Белоруссии с другими славянскими странами, [в:] Славяне в эпоху феодализма, Москва 1978.

Романова А. А., Сергеев А. Г., К истории Следованной Псалтыри из собрания Российской национальной библиотеки, „Вестник церковной истории”, 2001, № 3//4 (23//24), с. 327-330.

Сводный каталог славяно-русских рукописных книг, хранящихся в СССР (XIХІІІ вв.), Москва 1984.

Славова Т., Супрасълски сборник, [в:] Старобългарска литература. Енииклопедичен речник, София 1992. 
Славянские рукописи Афонских обителей, сост. А. А. Турилов и Л. В. Мошкова, под ред. А. Э. Н. Тахиоса, Фессалоники 1999.

Слюнькова И. Н., Монастыри восточной и западной традиций. Наследие архитектуры Беларуси, Москва 2002.

Срезневский И. И., Древние славянские памятники юсового письма, Санкт-Петербург 1868.

Срезневский И. И., Несколько припоминаний о Супрасльской рукописи ХI века, „Записки Императорской Академіи Наук”, Санкт-Петербург 1872, т. XXI.

Стефова Л., Супрасълски сборник, [в:] Кирило-Методиевска енииклопедия, ред. Л. Грашева, т. III, София 2003.

Строев П. М., Списки иерархов и настоятелей монастырей Российския церкви, Москва 2002.

Строевъ П. М., Списки іерарховъ и настоятелей монастырей Россійскія иеркви, Санкт-Петербург 1877.

Супрасльская рукопись, „Памятники старославянского языка”, Санкт-Петербург 1904, т. II, вып. 1, изд. С. Северьянов (przedruk: Gratz 1956).

Супрасълски или Ретков сборник (Заимов Й., увод и коментар на старобългарския текст, Капалдо М., подбор и коментар на гръцкия текст), т. I, София 1982, т. II, София 1983.

Творогов О. В., Черторицкая Т. В., Златоуст, [в:] Словарь книжников и книжности Древней Руси, вып. 2 (вторая половина XIV в. - XVI в.), ч. 1: А-К, отв. ред. Д. С. Лихачев, Ленинград 1988, с. 358-363.

Темчин С. Ю., Бытование древнеболгарского Супрасльского сборника в Великом княжестве Литовском в XVI-XVII вв.: новые данные, [в:] Преоткриване: Супраслъски сборник - старобългарски паметник от $X$ век, ред. А. Милтенова, София 2012.

Темчин С. Ю., Древнейшие рукописи Супрасльского Благовещенского монастыря (1500-1532 г2.): новые данные, [в:] Современные проблемы археографии: Сборник статей по материалам конферениии, проходивией в Библиотеке РАН, 25-27 мая 2010 г., ред. И. М. Беляева, Санкт-Петербург 2011.

Темчин С. Ю., О бытовании древнеболгарского Супрасльского сборника в Великом княжестве Литовском в XV-XVI вв., [в:] Этнокультурные и этноязыковые контакты на территории Великого княжества Литовского: материаль международной научной конферениии, Москва 2006.

Темчин С. Ю., Роль Матвея Десятого в православной культуре Великого княжества Литовского, „Latopisy Akademii Supraskiej”, Białystok 2010, vol. 1, (red.) U. Pawluczuk.

Темчин С. Ю., Рукописи Кимбаровского собрания Супрасльского Благовещенского монастыря (1532-1557 г2.), „Knygotyra”, t. LIV, Vilnius 2010.

Темчин С. Ю., Сколько книг было в Супрасльском Благовещенском монастыре в 1532 году, „Здабыткі”, Мінск 2010, вып. 12. 
Темчин С. Ю., Супрасльский список Хроники Георгия Амартола середины XVI века и его антиграф 1494 года, „Knygotyra”, Vilnius 2007, t. XLIX, s. 68-86.

Теодорович Н. И., Город Владимир Вольнской губернии в связи с историей волынской епархии: исторический очерк, Почаев 1893.

Теодорович Н. И., Историко-статистииеское описание волынской епархии, т. I, Почаев 1888.

Тихомиров И. А., О составе Западно-русских, так называемых Литовских летописей, „Журнал Министерства народного просвещеяия” 1901, № 3, № 5.

Турилов А. А., Антоний Супрасльский, [в:] Православная энииклопедия, т. II, Москва 2000.

Турилов А. А., Житие преподобномученика Антония Супрасльского и славянские жития балканских новомучеников XVI в. (к постановке проблемы), Hagiographia Slavica, (red.) von J. Reinhart, München - Berlin - Wien 2013 (,Wiener Slawistischer Almanach. Sonderband", Bd. 82), s. 265-273.

Турилов А. А., Заметки о кириллических пергаменных рукописях собрания бывшей Виленской публичной библиотеки (Ф.19 БАН Литвы), „Krakowsko-Wileńskie Studia Slawistyczne”, t. II, Kraków 1997.

Турилов А. А., Южнославянские памятники в литературе и книжности Литовской и Московской Руси XV - первой половины XVI в.: парадоксы истории и географии культурных связей, „Славянский альманах, 2000”, Москва 2001.

Улащик Н. Н., Введение в изучение белорусско-литовского летописания, Москва 1985.

Ульяновський В. І., Історія иеркви та релігійної думки в Украӥні: у трьох книгах, кн. 1: Середина XV - кінеи XVI століття, Київ 1994.

Флоря Б. Н., Владимиро-Волынская епархия, [в:] Православная энииклопедия, т. VIII, Москва 2004.

Церетели Е., Елена Иоанновна, великая княгиня литовская, русская, королева польская, Санкт-Петербург 1899.

Чамярыцкі В., Супрасльскі летапіс, [в:] Вялікае Княства Літоўскае. Энцыклапедыя ў 3 тамах, т. II, Мінск 2005.

Чистякова М. В., Текстологические особенности стишного пролога ГИМ, Увар. 56. - Kalbotyra 55 (2), „Slavistica Vilnensis”, Vilnius 2010.

Чистякова М. В., Текстология вильнюсских рукописных Прологов, Vilnius 2009.

Шахматов А. А., О Супрасльском списке западно-русской летописи. Летопись занятий Археографической комиссии, вып. 13, Санкт-Петербург 1901.

Щавинская Л. Л., Книжная культура православного Подляшья XV - середине XVI вв., „Е $\Lambda \Pi I \Sigma$. Czasopismo Katedry Teologii Prawosławnej Uniwersytetu w Białymstoku” 2000, R. II (XIII), z. 2 (15).

Щавинская Л. Л., Литературная культура белорусов Подляшья XV-XIX вв. Книжные собрания Супрасльского Благовещенского монастьря, Минск 1998. 
Щавинская Л. Л., Лабыниев Ю. А., Литература белорусов Польши XV-XIX вв., Минск 2003.

Щапов Я. Н., Восточнославянские и южнославянские рукописные книги в собраниях Польской Народной Республики, Москва 1976.

Ярушевич А. В., Ревнитель православия, князь Константин Иванович Острожский (1461-1530) и православная литовская Русь в его время, Смоленск 1897.

Ясіновський Ю. П., Украӥнські та білоруські нотолінійні Ірмолої 16-18 століть: Каталог і кодикологічно-палеографічне дослідження, Львів 1996.

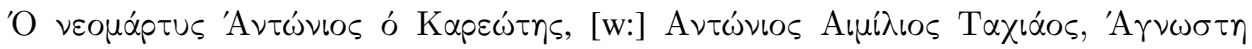

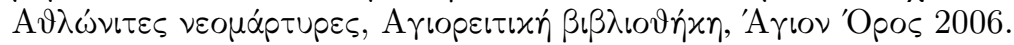

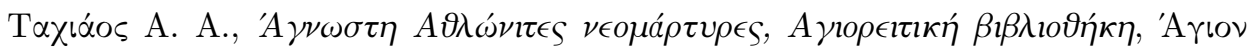
'Opos 2006. 